\title{
The influence
}

of hydro-climatological balances and

Nature-based solutions (NBS) in the management of water resources

\section{Małgorzata Gutry-Korycka}

University of Warsaw, Faculty of Geography and Regional Studies, Krakowskie Przedmieście 30, 00-927 Warsaw, Poland, e-mail: msgutryk@uw.edu.pl

\section{DOI: $10.26491 / \mathrm{mhwm} / 110415$}

ABSTRACT. This article offers a historical review of (cognitive) scientific research that demonstrates the development of key concepts relating to balances in the hydrological and hydro-climatic cycles, thereby supplying a basis for quantitative and qualitative assessment of renewable water resources. The review reveals the direction knowledge took as it developed through successive cognitive and applied stages. The emphases are on how global and regional hydrological conditioning underpin integrated concepts for the management of water resources. The primary aim of this article is to describe the main achievements, approaches and scientific initiatives, along with their theoretical underpinnings, in the hope of encouraging application and further appreciation. Attention is thus paid to milestones along the road to global development, as manifested in the (at times abruptly changing) effort to better assess and understand the use of water resources in various economic, social and ecological activities. The aim is first and foremost to encourage the achievement of sustainable development as humankind's main hope for the future. A further focus is on initiatives, scientific issues, and concepts that have been espoused by international organisations and illustrate the increasingly essential harmonious use of water resources at local, regional, continental, and planetary scales. Relevant global conferences have demonstrated wide readiness to adopt declarations, or to issue appeals and resolutions, in support of fuller assessment of renewable water resources. Examples of excessive use have been identified, and efforts have been made to counteract both floods and deficits, and hence avoid crises. These deliberations have also stimulated long-term forecasting, for periods up to 2030 or even 2050 . Also stressed here are the challenges, inspirations, and achievements of pure and applied science when it comes assessing the risk that the Earth's potential to supply water resources will be exceeded. The suitability of current assessments of water resources is evaluated, and reference made to ecologically-integrated answers such as Nature-based solutions (NBS), as backed by the UN and UNESCO (2018) in combination with principles set out in the EU's Water Framework Directive (2000/60/EC).

KEYWORDS: renewable water resources, hydrological-climatological water balances, approaches, concepts, Nature-based solutions (NBS). 


\section{FOREWORD}

The water in various forms that is an essential component of the geosphere is also a basis for the existence of our planet's living world or biosphere. Although water is a renewable natural resource, its quantity is such that the matter and energy associated with its presence in the epi-geosphere are limited. Key features include ubiquitous presence and uses in various sectors of the economy. The consequence is that water is a common economic good of great importance. Nevertheless, water resources are more limited by the overriding impacts of demographic, economic, climatic, and other anthropogenic factors than they are by natural renewability.

The main subject of interest here is the renewability of terrestrial water resources, i.e. the entirety of actually or potentially available water of suitable quantity and quality to meet defined demands (Międzynarodowy Stownik Hydrologiczny 2001).

This article seeks to achieve a synthetic, historically-based conceptualisation of the science of water resources, through which increasingly complex and technologically advanced methods can inspire more effective assessment and use of water. From the outset, integration of theory and practice has been a key pragmatic element bringing water management closer to more favourable solutions for utilisation, planning, and management.

The background to this article's content and objectives is provided by the natural shaping of the water cycle and its components in the environment, as the basis for quantitative and qualitative environmental aspects and the regularities underpinning spatial and temporal changes.

\section{IDEAS FROM SCIENCE}

AND PRINCIPAL CONCEPTS

\section{OF THE HYDROLOGICAL CYCLE}

Natural water circulation can be quantified in the form of the water balance that represents a basis for the management of water resources in an area and is also of fundamental significance to nature conservation. A basis for the water-balance equation is to be found in "the law or principle of mass conservation” as formulated by Einstein (1879-1955) - the very famous German physicist, creator of the general and special theories of relativity, and the person who emphasised the constancy of mass and energy, with the two nevertheless being interconvertible. This kind of thinking may ultimately trace back to $15^{\text {th }}$ century de- scriptive formulations arrived at by Leonardo da Vinci, not least in the matter of the water cycle within a drainage basin (Richter 1956). Biswas (1970) considered that da Vinci's work had led Newton (1643-1727) to his laws relating to the conservation of matter and energy, as well as gravitation. Circulation of water in nature as described by da Vinci makes visually clear the causes and consequences of many component processes that can be confirmed by simple measurement, attesting therefore to far-reaching scientific intuition about the interdependence of phenomena and factors. Premises supporting these concepts relate to spatial and temporal continuity and an unchanging quantity of water circulating in nature.

Craig et al. (2001) followed earlier hydrologists and geophysicists in maintaining that the amount of water globally remained constant, whereas this idea was not confirmed in research from the first decade of the $21^{\text {st }}$ century, not least from American astrophysicist Lewis (2012).

Documenting the further growth of knowledge about water, Biswas $(1965,1970)$ mentions Pallissy, active around 1550 in France and the developer of ideas about the origins of precipitation in a river system, as well as springs and underground waters. These concepts then offered the basis for assessment of renewable resources, as indeed Galileo, Descartes, and Gastelle (1 $17^{\text {th }}$ century) all proceeded to do.

Cognitive understanding of the hydrological cycle proceeded in stages. The American geophysicist Newton in his Encyclopedia of Water (2003) states that increased understanding reflected advances in measurement techniques, calculation methods, and scientific concepts, as accelerated by quantitative hydrology and mathematical modelling in the service of economic forecasts. The development of water balances was thus dependent on the length of measurement series and the scale of the analysed object (for example, a drainage basin or a floodplain).

According to Biswas (1965, 1970, 1978), true development of scientific hydrology took place in the $17^{\text {th }}$ century, with the first more-precise methods of measuring flows then representing a milestone in the development of quantitative resource assessment.

It was the second half of the $17^{\text {th }}$ century that brought the beginning of continental hydrology, much later termed global hydrology by Kalinin. Bierkens (2015) presented the contemporary state, trends, directions, and directives underpinning the development of knowledge about water resources.
Theoretical foundations for the assessment of water resources in scientific publications first gained support from real measurementsfromsuch large international rivers in Europe as the Elbe, Rhine, and Oder. Measurements began to cover a broader scale from the end of the $18^{\text {th }}$ century onwards, as intensive engineering work to regulate rivers was undertaken (see Biswas 1962, 1970 after: Maass 1870)

Representatives of the American engineering school associated with Stanford University in California, above all Linsley and Franzini (1972), devised strong theoretical foundations for the calculation of flowing water resources, as well as the behaviour of rivers at times of high-water events and flooding. From this point on, there was a broader movement seeking to put in place a rational model of calculating flows at times of flooding. The model was based on engineering studies involving 24-hour maximum precipitation and including factors such as evaporation, infiltration, and runoff via streams. Morley (1855), who was the biographer of Pallissy, thus dealt with a reconciling of theory and practice.

A key breakthrough in hydrology and its practical form (water engineering) was a modern handbook by Chow (1964) entitled the Handbook of Applied Hydrology. Even today it may not be described as outdated. In turn, those following the development of hydrology and water management in the USA should not ignore the modern Polish handbook from Lambor (1965), which offers a cohesive presentation of the relevant fundamentals, assessment methodologies, and management principles, as supported by numerous examples of problems and solutions arrived at on various continents and in many different regions.

\section{INTERNATIONAL DIALOGUE AND PROGRAMMES CONNECTED WITH WATER RESOURCES} AND MANAGEMENT

International interest in water, and particularly the resource and its quantity, use, management, and protection, arose in the mid-1970s and has continued to the present day under the auspices of the Geneva-based World Meteorological Organization (WMO). In the interests of forecasting and the methods of practical hydrology, the WMO issued a Fifth Edition (1994) of its guide for evaluating water resources. The role of the United Nations (UN) has become stronger as it strives more and more determinedly 
in the direction of joint international action, irrespective of whatever geopolitical blocs may be in place. It was on the initiative of that organisation that a first UN Conference on Water was convened at Mar del Plata (Argentina) in 1977. The main objective was an assessment of the status of water resources and a desire to assure all human beings access to water in appropriate quantity and of appropriate quality. Attention was paid to the socio-economic need for the water present on the planet, with further requirements that efficiency of use be increased, along with states' readiness to act in the face of a looming global water crisis, at the time considered likely to make itself felt before the end of the $20^{\text {th }}$ century.

A summary of established international political dialogue in the last 25 years of the $20^{\text {th }}$ century was produced for the Mar del Plata Conference by Biswas (2004). Key emphasis was then placed on global change in the Earth's water resources. The need for something to be agreed upon and established was widely recognised and emphasised, given what had been anticipated for the First Climate Summit (Conference of the Parties to the UNFCCC) held in Kyoto (2018 brought the most recent COP, COP 24, in Katowice). Rahaman and Varis (2005) published a key article on the state of management of water resources, with much emphasis placed on evolution, prospects, and future challenges, and stressed the need for integrated water management, which accounts for economic, social, and environmental/ecological aspects, as well as regional specifics.

Interlinkages between the systems of thought globally represent an issue of overriding importance supported by the UN, not least via its High-Level Panel on Threats, Challenges and Change. We also need to recall the precursors from Scandinavia who had significant input into the development of the sustainable development concept, including the future role to be played by water. Those in question were the then (1977) Prime Minister of Norway, Gro Harlem Brundtland, as well as Malin Falkenmark of the Swedish Academy of Sciences (in 1987). They regarded as crucial a holistic approach to meeting social, cultural, economic, and environmental needs where the uses of water and the environment were concerned. The World Commission on Environment and Development's Our Common Future report (1987) refers to climate change and its consequences for desertification, forest degradation and felling, water shortages, and the threat to biodiversity at the levels of the species, the biome and the phytocoenosis, most especially wet- lands, which are dependent on sources of water. This report was a key stimulus for further ground-breaking action in the name of what became known as sustainable development goals.

Falkenmark (1983, 1984, 1987, and 1991), and other international studies justified the protection of water resources in line with the growing risk or probability of the Earth's potential being compromised by the excessive use of water. She also, individually (1987, 1989/1990), and together with da Cunha (1989/1990) and others (1991), sought to justify strategies for the future development of the Earth that entailed an awareness of the protection and saving of water in planning and in other kinds of decisions such that the management of water might be optimised in the context of scale, factors, and preferences. Economic, social, and ecological aspects were propounded as being of the greatest importance.

Reports seeking to raise levels of knowledge and awareness of the sustainability of developments in water management include work brought out consecutively by the Intergovernmental Panel on Climate Change (IPCC 2007, 2012, 2013, 2014). Furthermore, relevant key events on the world scale included the "Earth Summit" convened in Rio de Janeiro in 1992, the Agenda 21 document associated with it, and the UN's Millennium Declaration and Development Goals, the last in force since 2015 and still binding.

It is also worth citing the article by Montanari et al. (2013), in which members of the International Association of Hydrological Sciences (IAHS) describe foreseeable changes that pose a threat to water resources globally. Subsequently, McMillan et al. (2016) maintained the IAHS stance, but emphasised global hydrological prospects, some looking very unfavourable because of the likelihood of increasing water shortages and desertification.

Rockström and Falkenmark (2014) also noted the development of methodology relating to resistance and economising on resources in the interests of human existence, with proposals of the kind referred to in Table 4.

Many recent studies deal with water resources as they relate to environmental limitations, farming systems, and human food security (Rahaman, Varis 2005; Springmann et al. 2018), while Kindler (2018) and Varis et al. (2017) address the matter of worldwide use of water by reference to just a few dimensions of the protection of those resources essential to the production of food items (not least those to be imported or exported).
The end of the $21^{\text {st }}$ century's first decade brought many new actions focusing on the relationship between ecology, the reshaping of water resources under the influence of global warming, and the capacity of water balances and the hydrological cycle to go on supplying water. Attention is given to ecological processes that affect water quality and quantity, limitations on evapotranspiration, and the barriers to the consumption of water resources in extreme circumstances involving droughts or flooding.

Rockström et al. (2014) - responding to Vörösmarty et al. (2010, 2013) - claim that a future bridge between ecohydrology and uncontrolled resistance on the part of the environment may give rise to dramatic Anthropocene phenomena and processes that will disrupt the sustainability of water resources worldwide.

Today the preference is for closed-cycle water management. This approach is economical with water resources and involves links in the chain that comprises abstraction from the environment, use, and discharge. Where there is considerable access to limited resources, synergies involving demographic processes (population increase), or a larger number of people placing a burden on the management of renewable resources, then renewability becomes limited and there is a lack of equilibrium that works to minimise values for resource use.

Influential accords reached through the work of international organisations from the end of the $20^{\text {th }}$ century through 2015 include those under the auspices of the UN, FAO ICSU, and the World Bank. The IGBP, IHD IAHS, IUNEP, and IWRM Programmes are involved, along with consensus texts from or relating to the ESSP and EEA, Future Earth, IHP UNESCO, the Club of Rome, the "Water for Life" decade, the Pope's 2015 Encyclical entitled Laudato $\mathrm{Si}$, and NGOs including such church-related examples as Listen to the cry of the Earth and the cry of the poor, as well as the Global Catholic Climate Movement.

The key issues for these accords address awareness of the use and consumption of water resources and special protection for areas of deficit or accumulation within cities. In each case excessive outflow is to be prevented, sustainability encouraged, amounts of wastewater reduced, and appropriate priorities determined. Drought represents a major challenge for agriculture, horticulture, livestock-raising, and forestry.

The distinguishing of the different types of water resources and their precise definitions (for example as green or grey water) reflects the way that water may be subject to various 
processes before it, for example, becomes effluent. It is possible to steer such resources, and engage in appropriate management or allocation of them.

Anticipated droughts and periods of low levels of surface water or groundwater as a reflection of global warming and excessive use have been worked on by Tallaksen and Van Lanen (2004). In turn, Veldkamp et al. (2015) draw attention to significant changes (and underlying mechanisms) in global shortages of water during the year, with implications for socioeconomic changes in agriculture and recreation. Moreover, Van Beek et al. (2011) reveal that even global monthly changes affecting meteorological events may tend to stress plants and limit access to water retained in the soil, which is needed if high yields are to be obtained. A recent report from Poljanšek et al. (2017) summing up knowledge on disaster risk management resorted to the perverse title "better to see it than to lose it".

In sum, such extensive, multi-dimensional development of knowledge of quantitative assessment in water-cycle management and balancing must include mathematical modelling (deterministic, stochastic, or conceptual). Beyond hydrology, environmental, and ecological factors, models will need to address economic and demographic development scenarios. The ultimate aim in each case is to make projections possible, with verification by way of measurement and monitoring, thereby supplying a basis for the forecasting of changes in the resource under the influence of various global and anthropogenic activities.

\section{THE DEVELOPMENT OF WATER-BALANCE PROBLEMS \\ AND CHALLENGES}

As the content of previous sections makes clear, the cognitive development of the hydrological cycle was a very protracted, step-bystep process extending from the $16^{\text {th }}$ through the $19^{\text {th }}$ centuries. It centred on a developing understanding of genesis and interdependence, and the uncovering of empirical premises confirming variability across both space and time. As Biswas $(1965,1970)$ shows, and Dooge (1959, 1974) confirms, opportunities arose for further qualitative and applied development, with quantitative indicators characterising a studied basin better and better integrated. An outline of the scientific thinking behind better acquaintanceship with the water cycle was imperative, with mathematical descriptions of the processes, given the need for real-life solutions, practical applications, and full insight into the renewability of water resources, the way they originate, and the way in which changes can be evaluated.

Recent centuries brought major developments to deriving hydrological balances for drainage basins. As Biswas (1978) notes, the concept of the hydrological cycle developed in France by Delamétherie (1743-1817) - albeit on the basis of ideas da Vinci outlined was the first approach seeking to account for an arithmetic regularity by way of mathematical description. It was then up to a water engineer from Leeds (UK) - Smeaton (1724-1792) to engage in the measurement of flow, although he did not conceive an algebraic equation by reference to the French findings.

The use of mass (or volume) balance as a means of both assessing and studying renewable water resources on the basis of mathematical description of the hydrological cycle has been employed since the end of the $19^{\text {th }}$ century. The form and application have remained the same through all this time, notwithstanding developments and a process of ongoing modification. The balance structure has always been based on the same assumption: that incoming amounts of water are equal to those passing out of a given area over a given time. However, choices then need to be made in line with the objective that is to be served. The mass balance, as the simplest of the mathematical models, may first need recalling here, even if it is probably well known.

Arising out of the laws of conservation of mass and energy, the water balance equation remains a numerical representation of the hydrological cycle characterising a drainage basin, and is still useful, albeit often now in forms that reflect ever-greater expansion, and methodological perfection. In classical hydrology, the terms used for the components of the water balance are used interchangeably with those applied to components or elements of the hydrological cycle. The balance for the catchment or basin of flowing waters, lakes, swamps or aquifers, including different components of the water cycle in the area under consideration, remains in close linkage with, and is very much conditioned by, various renewable sources of water, which are integrated by the processes of water cycling, whether on the surface, just below the surface, or deeper underground.

The development of hydrological balances proceeded in stages. The water cycle required dynamic and quantitative conceptualisation representing a basis for the management of water resources on different scales. It was accepted that this should be termed the water balance, and be time-related. The German geographer Keller (1980) followed Soviet hydrologist Lvovich (1969, 1974) and Mikulski (2006) in ascribing the form of the quantitative raw balance to Brückner (1862-1927), a German geographer-climatologist. The precise date and form of the equation for this raw balance of resources are not known, but can be hypothesised (after Mikulski 1998) as a 1904 innovation. The first form of the equation was simple, with atmospheric precipitation $(N)$ = river outflow $(A)+$ water loss $(W)$, this being written using the original nomenclature in German as:

$$
\begin{gathered}
N=A+W \\
\text { Niederschlag }=\text { Abflus }+ \text { Wasserverlust }
\end{gathered}
$$

Keller (1980) considered that the equation initially served (for example German geographer and geomorphologist Penck in 1896) in determining the flow in a river from a known precipitation total, in the case of an inadequate supply of measurement data. Rather earlier it had emerged, as an 1883 achievement of Polish water engineer Iszkowski (Mikulski 1998), that field evaporation might also be calculated as in Equation 1 from the difference between precipitation and river outflow ( $W-E$, where $E$ is evaporation). The year 2008 also marked the $135^{\text {th }}$ anniversary of the publication of Iszkowski's work, which used Penck's equation in its calculations, and went by a title approximately translating into English as On evaporation in the field. It was obviously concerned with the water cycle on planet Earth, but did not take account of the evapotranspiration process. It can be presumed that Penck and Iszkowski were well acquainted, thanks to contacts in Vienna and Lvov (at that time in the Austrian province of Galicja).

Penck's 1896 equation proved useful to the aforementioned Brückner (1904), and then to Russian hydro-engineer in the Don Basin Oppokov (1905), as they tried to account for differences in drainage-basin water balances over the long term, as compared with mean values (Mikulski 1998). To this end, an initial improvement involved a term for change in the level of retention $(\Delta R)$. An equation modified in this way has persisted to the present day.

The water balance thus came to be founded upon the assumption that, in a period $\Delta t$, 


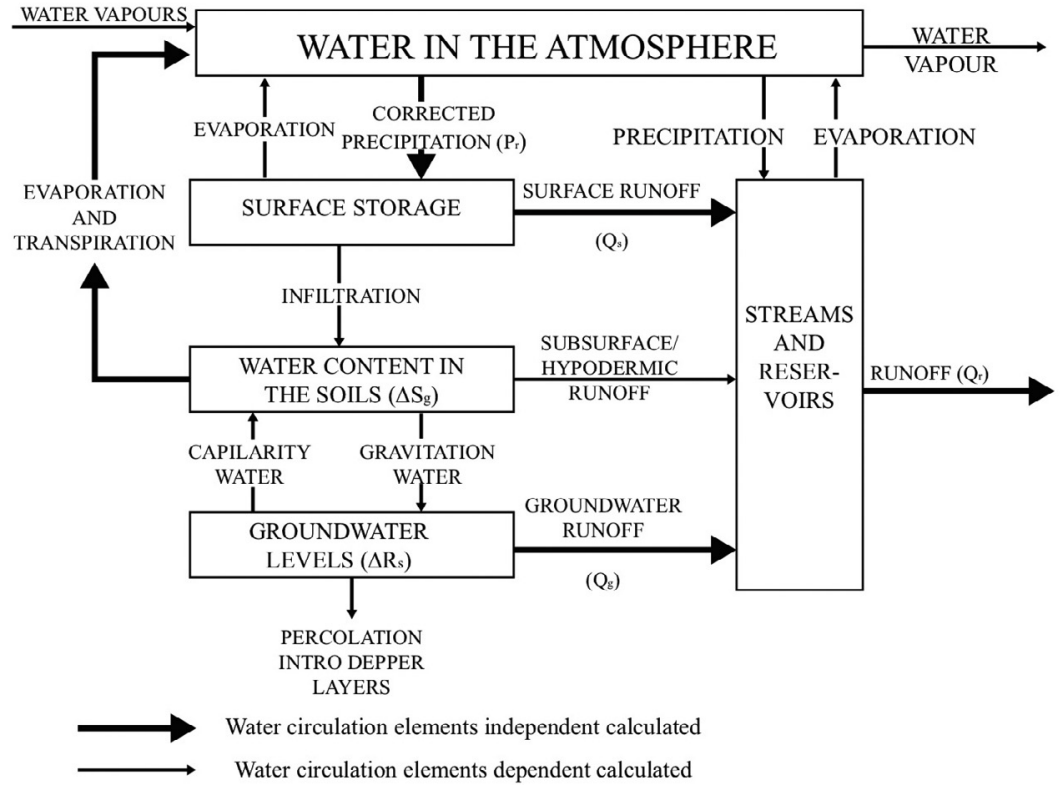

Fig. 1. Classical scheme for water circulation in the catchment (based on Soczyńska et al. 2003)

the total amount of water entering a given hydrological unit (drainage basin) is equal to the sum of losses plus any change (in comparison with the original) in the state of final retention. However, retention as a separate component was identified in the balance equation only thanks to Oppokov as the fraction of precipitation that reached the drainage basin, but neither flowed out nor evaporated, at least over the period under consideration.

A breakthrough in the assessment of drainage-basin processes and the development of water balances involved dividing the discharge hydrograph into surface and underground phases; as well as the method for assessing evapotranspiration. Application of mathematics, information technology, and the theory of systems in the 1970s and 1980s resulted in the development and use of systems-theory computer techniques. These developments supported the rapid, revolutionary development of mathematical modelling based on Bertallanfy's theories in describing the transformation of ever-larger empirical data sets (Haimes 1987; Soczyńska 1995). It became possible to apply an ever-greater number of generations of models, with the balance equation becoming the classical approach, alongside new ones, for example those involving graph theory, fuzzy sets, etc. Statistical and stochastic models (and among them dynamic water balances like CLIRU N-3) have contributed to the assessment of water resources on the basis of climatic or hydrological plus climatic data
(Kaczmarek 1996) integrated with variables characterising atmospheric or soil, vegetation-related, and riparian processes.

Rates of loss or gain of water resources may vary under various anthropogenic pressures, and may head in opposite directions.

Where the balance period is markedly shorter, there is a need to take account of dynamics of water and heat in a basin that can be safely ignored when the period is an annual one. The equation for the water balance then (after UNESCO 1971 and Lvovich 1974) ${ }^{1}$ is:

$$
P+R_{1}=H+E+R_{2}
$$

where: $P$ is precipitation; $R_{1}$ represents initial level of retention; $H$ is outflow; $E$ - evaporation; and $R_{2}$ - level of final retention.

This equation assumed the full form of the developed balance (Kędziora 1995), in line with:

$$
P_{r}+E+S_{p}+S_{g}+S_{a}+\Delta R_{s}+\Delta R_{p}+\Delta R_{i}=0
$$

where: $P_{r}$ represents precipitation in all its forms, $E$ is evapotranspiration (field evaporation); $S_{p}$ surface runoff; $S_{g}$ groundwater outflow; $S_{a}$ apotamic flow (percolation), $\Delta R_{s}$ the change in ground retention, $\Delta R_{p}$ the change in surface retention (in rivers, lakes, or wetlands), and $\Delta R_{i}$ the change in retention due to interception by plant cover (Fig. 1).
If water resources in a given precisely-defined area (basin) gain expression through a time function with a freely-selected time-step, then, as developed by Overmann (Soczyńska 1997) and Owens and Watson (1979), we arrive at the following 19-component version:

$$
\begin{gathered}
\left(P_{1}+P_{2}+P_{3}+P_{4}\right)= \\
\left(H_{p}+H_{f}+H_{g d}+H_{g}-H_{a p}\right)+ \\
\left(E_{w}+E_{p}+E_{t}+E_{i}+E_{c}\right)+ \\
\left(\Delta R_{p}+\Delta R_{a}+\Delta R_{f}+\Delta R_{g}+\Delta R_{a p}\right)_{\Delta \Delta t}
\end{gathered}
$$

where: $P_{1}$ constitutes precipitation measured $1 \mathrm{~m}$ above the ground; $P_{2}$ is the further amount of precipitation arising out of systematic measurement errors; $P_{3}$ is "horizontal" precipitation (involving rime or hoar frost and fog); $P_{4}$ is precipitation originating with the condensation of water vapour in the air as dew; $H_{p}$ is the surface outflow or runoff; $H_{f}$ the sub-surface flow out of the zone of fluctuation in levels of groundwater; $H_{g d}$ the inflow of groundwater into the basin; $H_{g}$ underground outflow into watercourses; $H_{a p}$ underground apotamic outflow into deeper rock layers; $E_{w}$ evaporation from open water surfaces; $E_{p}$ evaporation from soil, snow, ice or impermeable surfaces; $E_{t}$ transpiration by plants; $E_{i}$ losses due to interception by plant cover; $E_{c}$ losses reflecting chemical transformations; $\Delta R_{p}$ changes in surface retention; $\Delta R_{\mathrm{a}}$ changes in the aeration zone; $\Delta R_{f}$ changes in retention in the saturation zone relating to a variable water table. Then $\Delta R_{g}$ represents changes in retention of potamic groundwater (percolation); $\Delta R_{a p}$ changes in retention in the saturation zone of fluctuations of deep-lying groundwaters not associated with river drainage, and $\Delta t$ the time step for the calculations.

As can be seen, the development of such an equation requires the collection of a great deal of measurement data. Should that be lacking, we resort to empirical formulae allowing for direct or indirect estimation of some of the 19 elements of the cycling of water (or processes) considered to be operating in a basin. Sometimes consideration is confined to the more important factors, sometimes even to just one of them (Fig. 1).

As has been noted already, the dynamic hydrological balance in a natural basin can be expressed with a set of five subsystems, or even a greater number (Fig. 1), that are interlinked in the manner depicted in Equation 2. Conservation of mass and energy dictates that transformation of any component

'The geographical and hydrological method developed by Lvovich was dubbed his favourite son by colleagues. It was a six-element system for a balance equation (after Mikulski 2006). 
of the balance on either side of the equation influences the remaining components.

The dynamic balance for a natural drainage basin can have anthropogenic (water management-related) components incorporated into it, in relation to both incoming and outgoing resources. Quantitative and qualitative changes characterising the cycling of water and brought about by anthropogenic factors may arise throughout a basin, or in just a part thereof. Indeed, change may be confined to the channel of a single watercourse. Likewise, the impact involved may be episodic, short-lived, periodic, seasonal, annual, or multiannual, and is determined by physico-geographical (including climatic) conditions, compounded by the effects of various forms of economic management that modify retention, outflow, and evapotranspiration, or a connected basin. These factors are most often multi-directional and very difficult to assess objectively, especially because of the lack of a frame of reference, or initial, natural background conditions. It should be stressed that the directions of impact of anthropogenic changes may vary, and may sometimes be synergistic.

The compilation, in an independent or dependent manner, of all component elements of the balance described by the relevant equation should also be accompanied by a calculated error of estimation.

The equation balance remainder should be distributed between all components proportionally to their significance (Ozga-Zielińska, Brzeziński 1994). However, subsequent research has shown that these errors should not be distributed among all elements of the equation but expressed in an additional element, the socalled non-classed water balance $(\eta)$ :

$$
P_{r}-E_{t}-\left(H_{p}+H_{p}\right) \pm \Delta R-\eta=0
$$

UNESCO has recommended a version from Sokolov and Chapman (1971, 1974) after Sugavara, in which water-balance components must be evaluated in relation to their variability. The evaluation error of each balance element should then depend on the distribution and variance, measuring instrument accuracy and measurement frequency, subordinated to systematic and random errors.

The drainage dynamic water balance equation as written by Overmann (Soczyńska 1997 et al.) took the form:

$$
P_{r}(t)=H_{p(t)}+H_{g(t)}+E_{(t)}+R_{(t)} / \Delta t
$$

In such a complex, multi-element form, the water-balance equation is very difficult, if not impossible, to resolve for a small-scale cycle, with the result being duplication (double counting) of circulation caused by the protracted or short-lived presence of water by way of retention.

\section{PROBLEMS \\ AND CHALLENGES \\ SURROUNDING THE HYDRO-CLIMATOLOGICAL BALANCE}

The atmospheric nexus with the cycling of water is of particular importance, if hard to estimate. Measurement and calculation methods associated with it are very complex and have tended to accumulate ever more parameters as time has passed. The devising of balances for elements of the climate may resemble or be identical to those relating to the hydrological aspects, or else proceed with a different rhythm. Three links involving the exchange of matter and energy have been described in theoretical terms, i.e. the atmospheric $(A)$, the surface-related $(S)$ and the soil/ground/plant-related $(P, G)$. There are naturally interactions in play between all of these (Fig. 2).

Each of the evaporation processes (or types related to cover), e.g., field evaporation, evapotranspiration, guttation (interception by plant cover), requires a separate physical and mathematical approach (Monteith 1981; Kędziora 1995; Kowalik 1995, 2010; Jaworski 2004; Gutry-Korycka 2007). Three important ways of doing that are worthy of mention: (1) diffusion, as described by British physicist John Dalton in 1802 (as referred to in Biswas 1978; Szymkiewicz, Gą̧iorowski 2010); (2) the balance of heat energy encapsulated in equations developed by American astrophysicist I.S. Bowen in 1926 (Kędziora 1995); and (3) a concept relating to heat flux from Bowen, as well as Australian physicists Priestley and Taylor (1972), and British experts on evaporation and evapotranspiration Penman (1956) and Monteith (1981, 1985).

The greatest number of creative theoretical and empirical solutions were arrived at by agro-hydrologists of the Dutch school (de Wit 1958, 1965; Bierhizen, Slatyer 1965; Ritema 1969; Ross 1970; Ritema, Endrödi 1970; Feddes et al. 1980), whose work included the roughness of cultivated plants, increments in biomass, transpiration, interception, and various types of evaporation. Issues of gaseous exchange revolve around photosynthesis, as well as the exchange of greenhouse gases, with

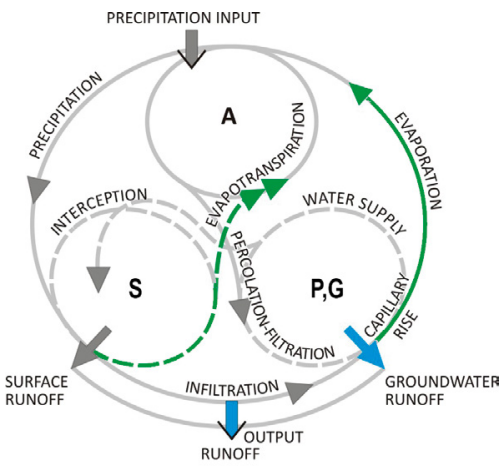

water circulation links: A - atmosferic; S - surface; $\mathrm{P}, \mathrm{G}$ - plant canopy, ground

Fig. 2. Water circulation links showing locations of blue, gray, green water (based on Kędziora 1995, modified by author)

much work undertaken by British workers, as well as Scandinavians (e.g., at Uppsala and Åarhus).

Meteorological parameters in the near-ground atmosphere such as solar radiation (as the main source of energy), wind, air humidity, and the kind of vegetation covering soil all help determine the intensity of the process by which the gaseous exchange of water takes place. It has long been known that a particular role in the transfer of water to the atmosphere is played by vegetation cover and soil processes. The biosphere must thus receive a considerable amount of water (thanks to interception or dew formation), and of that only a small proportion is used in the development of biomass. The remainder of this water participates in overall transpiration from plant cover (Figs. 1, 2 and 3).

Water passing through the plant root system (rhizosphere) through osmosis and capillary action reaches the atmosphere via fine vessels, though arrival at the leaf may coincide with photosynthesis, with mineral substances taken from the soil combining with carbon dioxide $\left(\mathrm{CO}_{2}\right)$ from the atmosphere, with the participation of solar radiation, to build plant organic matter. It has been shown that the amount of water conducted by a plant is a function of these processes.

Regardless of the specific biome, the total mass of a plant is proportional to the amount of water used during its growth. This is an important feature of the hydrological cycle, which Falkenmark (1984) termed (from the point of view of water resources and their designation) "green water" (Fig. 3). Matricon (2000), Hoffman et al. (2000), Hoekstra (2003), Mioduszewski (2003, 2006), Chapagain and Hoekstra (2004) in turn revealed that the production of $1 \mathrm{~kg}$ in dry mass of grain requires $\approx 500 \mathrm{~L}$ of water, whereas the production of a $1 \mathrm{~kg}$ of cotton needs twice as much. These ideas can be generalized to other crops, as well 


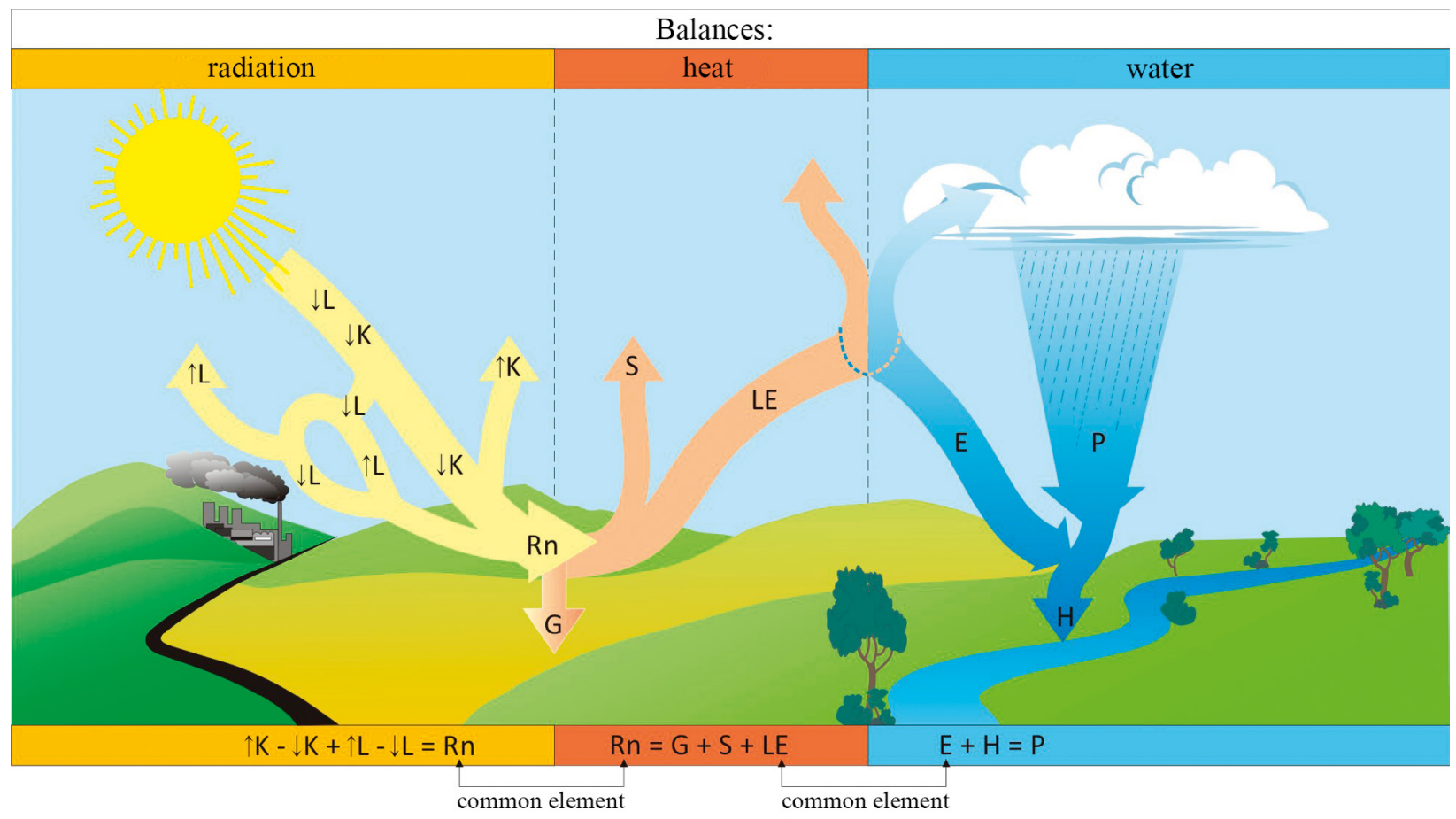

Fig. 3. Common elements of balances: heat, radiation, water balance (based on Kędziora 1995)

as goods for consumption or industrial uses; the concept dates to the start of the $21^{\text {st }}$ century.

Evapotranspiration is a dual process: the effect of a phase-change resulting from evaporation at the land surface and from plant cover, and transpiration due to the activity of individual plants or plant communities. While precipitation is taking place, most authors ignore evaporation, though some may adopt a value for it as potential evaporation $\left(E_{p}\right)$.

The simplest form of description nevertheless involves evaporation from the surface of a body of water, or from a solid object saturated in some permanent way. It is possible to mention two types of theoretical description of the process of evaporation. The first proceeds via transport with the aid of diffusion and the retention of mass (as theorised by Dalton in 1802). In the other, changes in the course of the process of evaporation are summarised as the amount used in the process of gaseous exchange, as change in water vapour per unit of time (Rodda 1953; Dobson 1977).

A method such as that involving heat balance allows for an estimation of the mean rate at which water is lost through the process of evaporation over a given time step. This method of approaching the issue gained dissemination very widely thanks to the school of American physicists founded in 1926 by Bowen and continued by many European authors, including the Briton Penman working in Australia (Penman 1956), as well as British physicists Thornthwaite and Ma-

ther (1957), Belgian agro-meteorologists van Bavel and Hillel (1976), British physicist Monteith (1985), Americans Gash and Shuttleworth (2007); and a well-known school of physicists and climatologists in the Soviet Union including Konstantinov (1963) and Budyko (1986).

In the approaches taken (and methods of calculation applied) up to now, appraisal of the processes determining levels of useable water resources include balances relating to radiation, to heat and to the active surface (i.e. the area of ground covered by vegetation, or else the open water surface). See Kędziora (1995) and Figure 3.

The common elements of the balance equations, with $R_{N}$ being the residue in the radiation and heat balances expressed via equations $7 \mathrm{a}-$ $7 \mathrm{~d}$, are as follows:

$\uparrow K-\downarrow K+\uparrow L-\downarrow L=R_{N}$
$\quad$ (radiation balance)

$G+S+L E=R_{N}$ (radiation balance)

$E+H=P$

(water balance)

$R_{N}=G+S+L E$

(heat balance) where: $\downarrow L$ is long-wave radiation reaching the land surface; $\uparrow L$ is long-wave radiation from the land surface; $\downarrow K$ is short-wave radiation reaching the land surface; $\uparrow K$ is short-wave radiation reflected off the land surface; $S$ is the flux of sensible heat; $L E$ the flux of latent heat; $G$ is the flux of soil heat; $E$ is the flux of water vapour; $H$ is the overall runoff into a river; $P$ is (real) atmospheric precipitation; and $R_{N}$ is the differential balance for radiation.

The first controlling factor in the radiation balance is the albedo of the active surface, which varies through the year and during the growing season, since it depends on the physical type of land cover, including for example forest, exposed soil, open water, or snow cover.

The accumulation of snow in a basin and the intensity of melting are the most important factors determining the rate and magnitude of outflow due to melting, as it proved possible to establish both theoretically and empirically thanks to the work of such American geophysicists and engineers as Wilson (1941), the U.S. Army Corps of Engineers (Snow Hydrology 1956), and Grey and Prowse (1993). Polish scientists have made a major contribution to our understanding of how to describe phase transitions of water in terms of the physics of the processes involved (Dobrowolski 1923). The energetic balance for the modelling of thaw processes in line with streams of energy and the energy balance - as the algebraic sum of all the streams inputting to the surfaces of snow cover and de- 
parting from them, and as entered into approximate equations (7a-7d) was applied by Kupczyk (1980) and Soczyńska (1997).

English ecologists, Calder et al. (1992) and Halder (1992) used the equation described. Plant canopy transpiration $(E)$ was estimated as the summation over a three-layer calculation with the Monteith-Penman formula according to Monteith (1965) applied at each level:

$$
\lambda E=\frac{\Delta^{\prime} H+\rho c_{p} \cdot \delta_{q} \cdot g_{a}}{\Delta+\left(\frac{c_{p}}{\lambda}\right)\left(1+\frac{g_{a}}{g_{c}}\right)}
$$

where: $H=$ the available radiative energy for each layer of the forest; $c_{p}=$ the specific heat of air at constant pressure; $E=$ transpiration rate; $g_{a}=$ canopy layer boundary conductance; $g_{c}=$ canopy layer stomatal conductance; $\delta_{q}=$ specific humidity deficit; $\Delta^{\prime}$ = rate of change of saturated specific humidity with temperature; $\lambda=$ latent heat of vaporisation of water; $\rho=$ density of air.

Following Landsberg (1986), radiation absorption by the forest canopy is approximated by the Beer-Lambert Law:

$$
\ln \left(\frac{I_{z}}{I_{o}}\right)=-k \sum_{i=1}^{z} L_{i}
$$

For example, for physiological studies in young Eucalyptus stands where: $I_{z}=$ the radiation beneath increasing accumulation of leaf area; $I_{o}=$ the net radiation above the canopy; $k=$ an extinction coefficient (taken in this case as 0.5); $L_{i}^{*}=$ leaf area index of layer $i$.

For each of the canopy layers, stomatal conductance, $g_{s i}$, was calculated as:

$$
g_{s i}=L_{i}^{*}\left(g_{s u i}+g_{s l i}\right)
$$

where: $L_{i}^{*}$ is the leaf area index at given canopy layer; $g_{s u i}$ is the stomatal conductance of the upper leaf surface; $g_{s l i}$ is the stomatal conductance of the lower lead surface.

An interesting solution proving useful in spatial and water management and arising out of the heat and water balance is to be found in Schierbeek (1980). In a series of studies, example solutions were provided for water quantity and quality, soil-change technologies, and the planning and economic dimensions of land use, capped by mathematical modelling of processes and mechanisms that control the cycling of water in agricultural areas and depres-

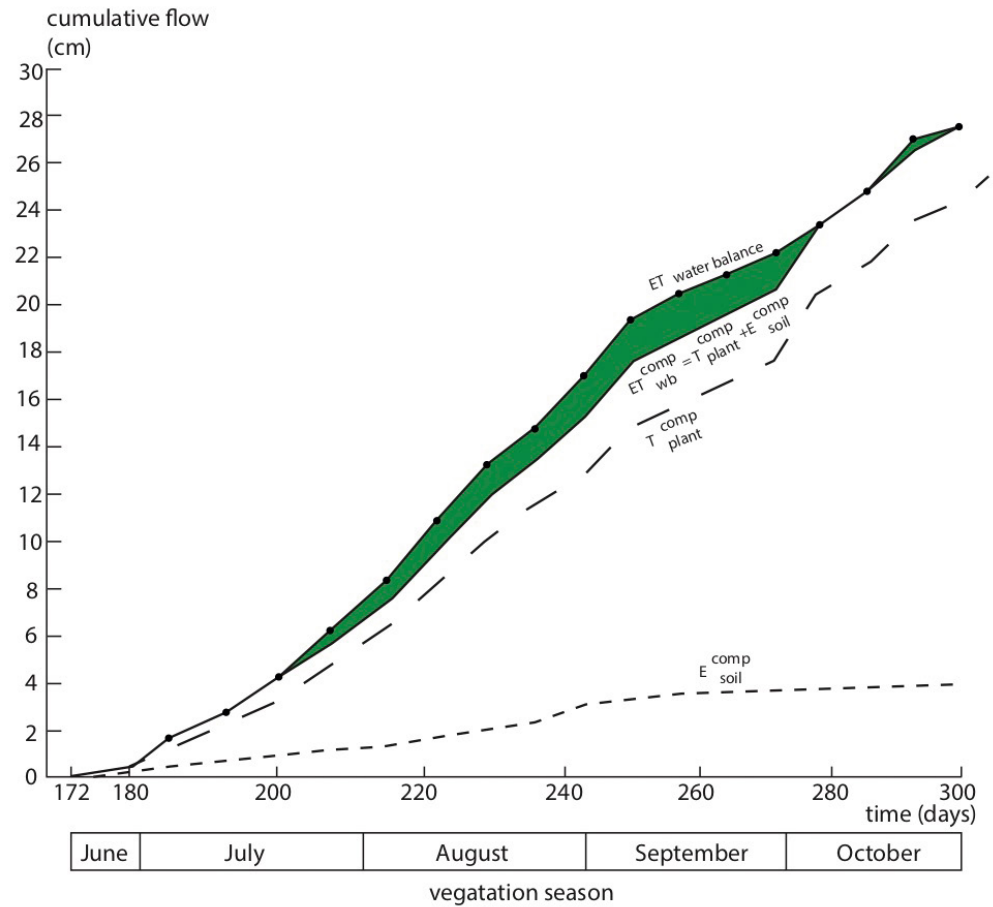

Fig. 4. Comparison of cumulative transpiration and soil evaporation as simulated with SWATR model with lisimetrically-measured data for a red cabbage crop growing on clay in the presence of a water table (based on Feddes et al. 1980)

sions. There is a high-level numerical description of infiltration into groundwater and aquifers. The modelling was partly achieved by using remote sensing for spatial identification of fields covered with various crops and the extents of different soils, in order to calculate net radiation $(L E)$ as a function of evapotranspiration, and with the growth of crops simulated (Fig. 4).

As presented by Feddes et al. (1980), an example illustrates the water circulation system that Falkenmark (1988) termed "short branch," with wetting and alimentation of an agro-ecosystem on clay soil.

The magnitudes of actual water resources conceptualised either pointwise or spatially in the soil (aeration) zone are determined by reference to the water balance, which is the difference between incoming water (the precipitation total with an instrumental correction, $P_{r}$ ) and water lost through evapotranspiration $\left(E_{t}\right)$, in a given place over a given period of time. This concept has been made clear empirically by such Polish climatologists as Łabędzki (2003), Wibig (2012), Wypych and Henek (2012), Kożuchowski (2014), Wibig (2017) and Wypych and Kowanetz (2017). They all deploy a rather different concept that determines a value for the water balance on an areal basis, with changes in retention ignored by means of longer-term averaging. In Polish, this is the Klimatyczny Bilans Wodny, i.e. the Climatic Water Balance $(C W B)$, defined as the difference between the corrected mean total of atmospheric precipitation $(P$,$) and the mean total potential evapotranspira-$ tion $\left(E_{p}\right)$, also termed indicative evapotranspiration, which is expressed as a water-column layer a given number of millimetres deep.

Evapotranspiration depends on the amount of accessible energy at the vegetated active surface. Quantitatively, this energy is the same as the solar radiation balance after Equation 7. Potential evapotranspiration may thus be denoted by one of several dozen formulae or empirical functions derived from one, two, or many meteorological parameters. Negative values assumed by the $C W B$ indicate prevalent $E_{p} \geq P_{r}$ during the growing season, with a shortage of precipitation determining poor conditions for renewability of water resources. In long-term forecasting associated with agriculture's demands for water, $C W B$ may be helpful in ensuring that greater harvests are obtained.

Other indicators of aridity of the atmosphere include a ratio of evapotranspiration to precipitation equated to a standardised empirical function corresponding to $R_{N}$ as the product of the latent heat flux and precipitation. This indicator was proposed by Budyko (1977, 1986). 
In summary, the water-balance equations presented in Sections 4 and 5, in their various forms, can be used in different approaches to the management of water resources, when incorporated into planning. Large amounts of data are required as well as adoption of different forms of the equation depending on the premises governing water use.

In relation to a type of economic planning, Lambor (1965), a well-known water-management specialist, drew a distinction between seven different categories of balance: the original or historical, the raw current (full or resource-related), the utilitarian, the planned, the prospective, the operative, and the dynamic. The choice then depends on the objective of the balance being estimated and the needs of water management itself.

The original or historical balance is related to the past, but still within either the Holocene or (if recognised) the Anthropocene. It entails the reconstruction of the cycling of water in the past, the aim being to research conditions in previous times, as well as trends associated with development.

The raw balance is a compilation of natural resources and losses within a defined area over a studied period of time, with no delving into uses and needs. Devising the balance involves reporting of incoming and outflowing water, as well as losses; with no account being taken of water use.

The natural or raw water balance may even take in all elements of the balance equation. If we confine ourselves to just two elements depicting water resources, i.e. precipitation and outflow, then what is being considered is a natural balance and a resource-based balance including field evaporation and retention.

The utilitarian balance presents, not so much the real state of water resources, as the state of use (reserves, consumption, and demand), with no account taken of changes in cycling and use, even though these factors may turn out to be necessary at a further stage of development. This balance is part of the wider static balance category.

The planned and prospective balance involves forecasting resource use and directing planned management in line with a development plan that takes account of an area's possibilities where resources are concerned. This is a dynamic conceptualisation.

The prospective balance, covering a period of 25-30 years, is at the same time a balance of the planned type.

The operative balance depicts the development of a planned balance as applied practically.
It describes a dynamic configuration of incoming and outflowing water over time and within a given spatial unit.

The forms taken by the equations vary, as does the number of (independently) calculated elements.

Each form and each category relating to balances in the hydrological cycle may gain application in comparative or reconstructive studies (i.e. the recreation of the state of quasi-original water resources), or can serve in forecasting by way of a dynamic approach.

\section{INCREASING CRISIS IN WATER RESOURCES - DROUGHTS}

At the beginning of the 1980s, a dialogue and broad discussion commenced about the prospects for the development and protection of water, especially drinking water. Concrete actions began to be taken by such international organisations as the UN, WMO, IHD UNES$\mathrm{CO}, \mathrm{ICSU}, \mathrm{WHO}, \mathrm{FAO}$ and many others (Section 3).

At that point, Sweden initiated a specific activity under the auspices of IHD UNESCO, ICSU, and IAHS, the newly-established IGBP and IGU, the WMO, etc., the main aim being to ensure the development of water management, to devise key directions and principles relevant to the use of renewable resources, and to identify barriers, factors, and restrictions. There is a justified need to apply methods from different disciplines, such as geochemistry, economics, biology, the social sciences, humanities, and ecology. The relationship between the rate of use of water and its quality must be considered, as well as the causes of limited-scope renewal surrounding changes in resources.

As her many studies show, Falkenmark (1983, 1984, 1989a-b; Falkenmark et al. 1991) played a pioneering role in formulating principles and devising ways of using surface and ground waters in relation to locations of intakes and with categorisation by precise criteria.

Thus far, the technical and ecological principles in force for intakes of water involve importing the water from source (underground) parts of a basin, with export taking place downstream. This dynamic has hydrodynamic and geochemical implications and is related to the way in which processes of self-treatment or self-purification operate. It is further qualified by water-use or water-consumption categories (Table 1).

This categorisation takes account of the objective of water use in relation to the form of hu- man activity; it might entail types of economic sector, infrastructure, or environment, as Falkenmark et al. (1987) considered. The principal categories are related to types development, e.g., towns or cities, housing estates, villages, or industrial plants. A further category entails the irrigation of cultivated fields. Irrevocable losses have also been taken account of as a total (relating to forests, other areas used in agriculture, and pastures, and also in relation to whether these areas are subject to melioration, drainage, or irrigation).

Further pursuit of this kind of concept was facilitated by a debate organised in Stockholm on awareness of needs for water development, with primary barriers to its use identified, along with bases for renewable resources. The expectation was that measures would be introduced in relation to different groups in society, with different strategies pursued and different organisations working to resolve conflicts at different levels. Those involved ranged from the authorities to individual consumers, to high-level regional representatives, and these all gained representation in the multidimensional matrix devised by da Cunha (Table 2).

The objectives here are political or related to group preference, and also related to different emotional approaches to the matter of water shortage. Discussions centred around the devising of targeted activity to help understand the factors determining renewal in aquifers, as well as self-purification of waters subject to pollution, in order that water suitable for drinking may be obtained.

At the same time, attention has been paid to the regulations with which water-supply systems are managed, with account taken of decision-making about risks, needs and threats.

Castenson (1989/1990), Falkenmark (1989/1990) and Hoffman et al. (2000) sought to draw conclusions about how the consumption of drinking water should be prioritised in its var ous social, economic, and environmental aspects. Consideration was also given to the rate at which resources are consumed, and the influence of consumption on pollution and water quality. This is what da Cunha (1989/1990, page 27) did, by developing a suitable analytical matrix.

Awareness of the uses of water resources should respond to different levels of human activity engaged in at different levels of administrative organization.

Falkenmark and Chapman (1989) further presented (as in Fig. 5 here) a scheme relating to water needs with reference to the macro-perspectives of various countries. The intake of re- 
Table 1. Principal categories of water use (based on Falkenmark et al. 1987; da Cunha 1989/1990)

\begin{tabular}{|c|c|c|c|c|}
\hline & \multirow{2}{*}{ on site } & \multicolumn{3}{|c|}{ Location of water use } \\
\hline & & in stream & out stream (withdrawal) & \\
\hline \multirow{3}{*}{ Economic sector } & $\begin{array}{l}\text { Agriculture, } \\
\text { Forestry aquaculture }\end{array}$ & $\begin{array}{l}\text { Rainfall in agriculture } \\
\text { Forestry } \\
\text { Swamp and wetland habitat } \\
\text { Utilisation of estuaries }\end{array}$ & $\begin{array}{l}\text { Fish and wildlife } \\
\text { Utilisation of estuaries" } \\
\text { Waste disposal }\end{array}$ & $\begin{array}{l}\text { Livestock } \\
\text { Irrigation }\end{array}$ \\
\hline & Industry & $\begin{array}{l}\text { Hydropower } \\
\text { Waste disposal" }\end{array}$ & $\begin{array}{l}\text { Steam power in kitchen } \\
\text { Mining" } \\
\text { Cooling } \\
\text { Processing" } \\
\text { Hydraulic transport }\end{array}$ & $\begin{array}{l}\text { Hydropower } \\
\text { Waste disposal" }\end{array}$ \\
\hline & Infrastructure & $\begin{array}{l}\text { Navigation } \\
\text { Recreation } \\
\text { Aesthetic enjoyment } \\
\text { Waste disposal" }\end{array}$ & $\begin{array}{l}\text { Drinking } \\
\text { Domestic uses } \\
\text { Public uses in settlements }\end{array}$ & $\begin{array}{l}\text { Navigation } \\
\text { Recreation } \\
\text { Aesthetic enjoyment } \\
\text { Waste disposal" }\end{array}$ \\
\hline
\end{tabular}

* - highly consumptive use; ** - heavy impact on water quality

Table 2. Matrix for identification of primary barrier group in implementation of water awareness at different activity levels (based on da Cunha 1989/1990)

\begin{tabular}{|c|c|c|c|c|}
\hline \multirow{2}{*}{ Type of barrier* } & \multicolumn{4}{|c|}{ Perspectives/Dimension } \\
\hline & Strategic & Societal & Organisational & Conflict-solution \\
\hline $\begin{array}{l}\text { Structural } s \text {-level } \\
\qquad \begin{array}{l}\uparrow \\
\downarrow \\
\text { Individual } i \text {-level }\end{array}\end{array}$ & $\begin{array}{l}\text { Problem perception and recognition } \\
\text { Communication modes } \\
\text { Degrees of freedom for action }\end{array}$ & $\begin{array}{l}\text { Political goals } \\
\text { Actor/Group preferences } \\
\text { Emotional differences deficiency }\end{array}$ & $\begin{array}{l}\text { Institutional setting } \\
\text { Power distribution } \\
\text { Public participating }\end{array}$ & $\begin{array}{l}\text { Ideological differences } \\
\text { Vested interests } \\
\text { Cognitive differences }\end{array}$ \\
\hline
\end{tabular}

* recognised as primary barrier group for implementation of water awareness at different statistical s-i levels

Table 3. The categorisation of water resources by reference to use classes (based on Milly et al. 2008)

\begin{tabular}{|c|c|l|}
\hline \multicolumn{2}{|c|}{ Water resources } & \\
\hline Classes & {$\left[1,000 \mathrm{~m}^{3}\right.$ per capita per year $]$} & \\
\hline 1 & $>10.0$ & Limitations in logistics management \\
2 & $10.0-1.6$ & Fundamental management problems \\
3 & $1.6-1.0$ & Water stress \\
4 & $1.0-0.5$ & Chronic lack of water \\
5 & $<0.5$ & Barriers to management \\
\hline
\end{tabular}

Table 4. Categorisation in relation to the scale of flow of water resources (based on Rockström, Falkenmark 2014 after: WRI 2014)

\begin{tabular}{|c|c|c|c|}
\hline \multicolumn{2}{|r|}{ Water resources } & \multicolumn{2}{|c|}{ Intervals for values of water resources $\left[1,000 \mathrm{~m}^{3}\right.$ per capita per year] } \\
\hline Classes & Sections & $\begin{array}{l}\text { Rockström, Falkenmark } \\
\text { (2014) }\end{array}$ & $\begin{array}{l}\text { World Resources Institute } \\
\text { (2014) }\end{array}$ \\
\hline 1 & Below a barrier of water management & $\leq 0.50$ & $\leq 1.00$ \\
\hline$\|$ & Frequent lack of water & $0.50-1.0$ & $\leq 1.00$ \\
\hline III & Water stress & $1.0-1.60$ & $1.1-1.70$ \\
\hline IV & Fundamental problems of resource management & $1.60-10.0^{\circ}$ & $1.70-5.00$ \\
\hline $\mathrm{V}$ & Limited resource management problems & $1.60-10.0^{\circ}$ & $5.00-15.00$ \\
\hline $\mathrm{VI}$ & No fundamental management problems & $\geq 10.0$ & $15.00-50.00$ \\
\hline VII & Plenty of water & - & $\geq 50.00$ \\
\hline
\end{tabular}

* - Rockström, Falkenmark (2014) introduced the same limit values (thresholds) in classes IV-V

newable water, considered in a traditional way (treating water as a technical factor), or else in an ecological way, whereby agricultural output is accounted for, inter alia. Need for water presented with the aid of a block diagram includes and illustrates two cases, of which one is traditional, relating to endogenous water resources available for use as opposed to lost; and the other is ecological, in that it includes water available for plant production (in forests, fields, and meadows), and accounting for production losses as given by the difference between outflow, precipitation and evaporation.

To sum up, in the 1980 s there was a (still-topical) major change in approaches to water-resource use, with decision-makers taking more and more account of new developments in water management, and renewable resources taking their rightful place in line with economic, social, and ecological considerations.

\section{MEASUREMENT OF THE DEFICIT IN RENEWABLE WATER RESOURCES}

The growing deficit in flowing and underground water resources was raised by the UN as a worldwide problem as early as in 1992 at the Rio de Janeiro "Earth Summit”. However, the resulting Agenda 21 (Adoption of an Agreement on Global Environment and Development) was not at that stage determined enough in its justification for the need to confine civilisation's development by having it save on water use and manage resources better in areas of water deficits, where climate change is also contributing to water shortages.

Further reports, signed declarations and report syntheses, including reports from Kindler (2009, 2014, 2016), the 2013 IPCC Report, and the Millennium Development Goals (2015) also confirm empirically, growing shortages of water as reflections of ever-greater instability of the climatic and hydrological cycles. These shortages are exacerbated by the increasing demands for water imposed by different branches of the economy, by agriculture, and by human needs in general.

The $3^{\text {rd }}$ World Water Forum was hosted by Japan in 2002, at Kyoto University. 
The Forum undertook an overall assessment of the Earth's resources of water in the context of risk and demand, inter alia for the melioration or irrigation of areas producing crops. Drip and areal irrigation systems were found to increase the biomass of above-ground parts of plants and roots, as well as transpiration, interception, and guttation. The amount of water taken up by plants determines water-balance structure (bearing in mind the retaining or expending of resources), while limitations on farm output in times of deficit are considerable, especially in the semi-arid zone. Evaporation in areas of rice cultivation is found to be increasing (de Wit 1958, 1965, 1969; Stanhill 1960).

Crop yields $(Q)$ can be calculated by reference to the simple formula in Equation 11. i.e.:

$$
Q=A_{1} \times W
$$

where: $Q$ is the $\left[\mathrm{kg} \cdot h \mathrm{~h}^{-1}\right]$ dry-mass yield of plants; $W$ the cumulative amounts of water transpiring [in $\mathrm{mm}$ ]; and $A_{1}$ a coefficient $\left[\mathrm{kg} \cdot \mathrm{ha}^{-1} \cdot \mathrm{mm}^{-1}\right.$.

It should be added that Stanhill (1960) was

able to show how the value of the coefficient $A_{1}$ in the case of grasses (including rice in paddies) - depends on climate and latitude.

The amount of water abstracted for economic purposes is increasing, thereby lowering water tables and reducing the flows of rivers (especially the smaller ones).

The Kyoto Water Forum included discussions on ways of calculating total amounts of water needed for biomass production (including food production). In the process by which plants develop, an important role is obviously played by evapotranspiration. However, beyond that, "technological" water is needed in livestock rearing and in the processing of food products. The amount of water needed to achieve a unit of output is, as Hoffman et al. (2000), Hoekstra (2003), and Chapagain and Hoekstra (2004) declared, the so-called virtual water, as described by the water footprint. This change in how water-resource use (and especially the consumption of high-quality water) is assessed is being debated more and more, even though it was once ignored. However, if consideration is given to unit demand for water in the production of food and industrial goods, it is clear that requirements are greater, as Table 5 makes clear.

A further global milestone came with the introduction of a key new process, Integrated Water Resources Management (IWRM). In IWRM ecological value is assigned to water, and it has become a priority in relation to the UN's Sustainable Development Goals.

In the wake of this activity, work commenced on potential water deficits and shortages, including a classification of relative availabilities.

The synthesis adopted thus far on the basis of reports from the European Environment Agency (2012a-b, 2018) points to progress achieved with access to water, a service offered to countries by the European Commission. A good example is also found in the Rome Report of the FAO agency responsible for food security. However, it needs to be realised that the climatic and hydrological balance and other proposals put forward by Budyko $(1977,1986)$ are too simplistic to suffice for long-term assessments, e.g., in regard to hydrological drought. In contrast, they would seem adequate to describe meteorological drought (Tallaksen, Van Lanen 2004).

The scale of assessment of water resources in relation to consumption is not uniform, however; though it may for example be presented in the form of an index of the economy's need for water. On average this would be 80-100 L per capita per day, according to the WHO, after Mikulski (1998), Gutry-Korycka (2018), etc. Beyond that, a measure of water resources in the economy may involve the index of water stress, denoting a water deficit (shortage) unfavourable from the points of view of people and plants and animals. Excesses of water (the inundation or submerging of soils and vegetation) disturb physiological processes, limiting or preventing crop production and affecting the amounts of fresh or dry biomass produced.

Those considering the measurement of amounts of renewable water resources should account for the average resources of flowing water as the so-called unit resources of water expressed gross and per capita. Gutry-Korycka $(2014,2018)$ holds that the post-War years (1946-2014) in Poland saw this amount vary over the range $1,090.6 \mathrm{~m}^{3}$ per capita (in 1990) to $2,767 \mathrm{~m}^{3}$ per capita (in 1948 ), with an average per-capita value of $1,824.3 \mathrm{~m}^{3}$. Gross water resources in successive years reflected variability in replenishment by precipitation combined with the consumption of water and increasing human population size.

In the face of modest renewable resources at times of water deficit, in-depth work on the use of green, grey, and blue waters is needed, in areas of advanced urbanisation in particular. Confining considerations to blue water and management is not adequate. It is also important for a distinction to be drawn between permanent water shortages brought about by human activity, and drought that is the result of climate change.

The importance of water to the economy and to the existence of human beings and nature is clear enough. It is therefore worth citing the most recent $\left(44^{\text {th }}\right)$ Rome Report from the FAO Committee on World Food Security, which refers to environmental threats diagnosed with full argumentation regarding their importance to development and the unfavourable influence exerted on long-term change. Reference is made there to new proposed solutions, and to changing renewable resources (von Weizsäcker, Wijkman 2018). This direction is congruent with the content of the Declaration from the Earth System Science Programme (ESSP) issued in 2008 as the so-called "Cape Town Declaration" (Ericssen 2008). Directions for contemporary science and geopolitics are also set out, with a view to urgently making humankind more aware of the threats facing the Earth as a whole. Much emphasis is put on indicating key ways in which to counteract the chaos present in urban and rural development around the world, with reference made to the so-called "soft development factors".

Furthermore, in the English language the concept of well-being has been introduced in reference to health, family, and quality of life (Czerny 2008; Gutry-Korycka 2009; Delang 2018). Among the key factors underpinning existence in this conceptualisation are access to housing, and the means of obtaining energy for heating and the preparation of meals. There is also a strong acceptance of the need for factors helping to safeguard life, such as drinking water, food, cultivated land, means of sanitation, and access to toilets, medicines, and healthcare.

In summary, Drogers and Immerzeel (2008), Brown and Matlock (2011) stress that the matter of access to water, especially that needed for drinking, sanitation and irrigation, has assumed priority status, especially in areas faced with considerable shortages.

Optimal use of water resources to meet a whole range of municipal, agricultural, industrial, energy, recreational, and tourism goals should accord with appropriate water-management decisions based on knowledge, targeted action, and astute strategic thinking. The fundamental resources of water are what are termed "blue" by Falkenmark (1986), and Falkenmark and Rockström 
(2004). This water may be augmented by socalled "grey water," i.e. effluent from any uses that do not involve faecal contamination. At one time, precipitation was not regarded as a significant contributor to the renewability of water resources. Today, however, greater deficits in the availability of blue water dictate that grey water should undergo treatment to be reclaimed as a resource. Grey water originates as effluent from urban infrastructure, as runoff from peak high-water events, and as a component of the superficial groundwater layer. Volumes of grey water are determined by processes taking place on the land surface in urban areas, tending to augment short-lived retention at the surface, reflecting the presence of infrastructure. However, this water can also be used, for example, as a component of green water.

Efforts to prevent ever-greater shortages of water in urban areas, involving economic impact, require instruments effective in the management of renewable resources, as well as relevant regulations. Crisis surrounds the greater demands for water exerted by the populations of cities, as opposed to the efficiency of urban infrastructure. Shortages of water are thus increasingly a significant barrier to society's sustainable development (World water supply and demand in 2025 2000; Rijsberman 2006; Stern 2006; Więcej niż niedobór: władza, ubóstwo i globalny kryzys wodny 2006; Drogers, Immerzeel 2008; Kundzewicz, Kowalczak 2008; Gerten et al. 2015; Steffen at al. 2015; The Milennium Development Goals Report 2015). Barriers associated with water shortages include a value for the index of water stress that represents an unfavourable situation for the soil and the plant canopy. In turn, there may be a water deficit in the context of a drought period; or else an excess leading to flooding and puddle stagnation that is unfavourable for retention by the soils and plants (green water).

Water stress has been related to human beings by many authors (including Milly et al. 2008 and Rockström et al. 2009), with quantification mostly involving a subjective 5-point scale (Table 3).

A new approach to the protection and use of water resources (and the reduction of deficits) was announced by the UN in 2005, in the context of the International Decade for Action "Water for Life". Regulations for the protection of water resources and the right of human beings to potable water and sanitation were in turn agreed upon in 2010 (Huntington
2010). Natural rights form part of classical ethics and are near-ecological in character; because humans need water, they have a fundamental right of access. Of course, giving effect to such concepts inescapably implies a just division and assignment of water resources - a matter that assumes considerable significance where deficits are common. Likewise, Pope Francis in his Laudato Si Encyclical of 2015 drew attention to the exhaustion of water resources through excessive consumption and worsening deficits, as well as the matter of the deteriorating quality of those resources. It needs to be added that prospects for socioeconomic development, including water management, are very much linked with the future management of resources, guided by key premises regarding water saving, and the fact that water is a common good that every human being has the right to use (Gutry-Korycka 2017).

The optimal future solution for limiting water deficits entails equilibrium among the economic, social, and ecological pillars, (i.e. sustainability), thereby then providing a basis for the achievement of an appropriate, if limited, degree of tolerance most closely resembling nature's principles and processes.

Development and urban sprawl go hand in hand with population growth and ever-increasing population densities in many parts of the world, leading to a rapid reduction in water resources, and concomitant deficits. A question therefore arises concerning the directions that might be followed to ensure reduced use and consumption of water. The need for conservation applies to drinking water, precipitation water and its retention, the water in aquifers, and the water assigned to the irrigation of plants, whether naturally-occurring or cultivated. A primary constructive action would be to ensure the collection and retention of water at or close to the places where precipitation falls on roofs, terraces, and balconies in continuously or partially built-up areas, but also on playing fields, lawns, and squares; all the time seeking to ensure that water is not wasted through rapid (and also polluted) surface or near-surface runoff, from where it goes to sewers or the storm drainage system.

Estimates made in cities suggest that the index for surface cover of an impermeable nature is $100-150 \mathrm{~m}^{2}$ per person on average, in Poland; whereas the WHO suggests that this index should be less than $50 \mathrm{~m}^{2}$ per person on average. Urbanisation is associated with ever-greater sealing-off of the substratum, which increases detention of water on the surface (wetting),
Table 5. Average capacity of virtual water footprint for the selected products (based on Mioduszewski 2006)

\begin{tabular}{|l|c|}
\hline Product/weight or volume & Capacity of virtual water $[\mathrm{L}]$ \\
\hline sheet of paper A4 $\left(80 \mathrm{~g} / \mathrm{m}^{2}\right)$ & 10 \\
\hline slice of bread $(30 \mathrm{~g})$ & 40 \\
\hline apple $(100 \mathrm{~g})$ & 70 \\
\hline glass of beer $(250 \mathrm{ml})$ & 75 \\
\hline glass of wine $(125 \mathrm{ml})$ & 120 \\
\hline glass of coffee $(125 \mathrm{ml})$ & 140 \\
\hline glass of milk $(200 \mathrm{ml})$ & 200 \\
\hline hamburger & 2,400 \\
\hline cotton shirt $(500 \mathrm{~g})$ & 4,100 \\
\hline pair of shoes (leather) & 8,000 \\
\hline
\end{tabular}

while the resources available for human uses are reduced markedly as a result (Gutry-Korycka 2003; Natural Infrastructure: Investing in Forested Landscapes for Source Water Protection in the United States 2013; Gutry-Korycka 2018). It needs to be stressed that the utilisation and waste of water in cities is of key relevance to sustainable development, relating to rational intake and use in the forms of production and consumption. The objective is to counteract wastage of water with the possibility of uptake via infiltration and retention, in this way effectively ensuring that, irrespective of the season of the year, overburdened and overstretched pipeline waters can be replaced by precipitation. Gardens hanging on walls or located on roofs and terraces join gardens, parks, squares, etc. as biologically active areas in which evaporation and transpiration are enhanced. Economies in the use of water resources can be achieved in this way, as can increases in available resources, without any increase in fees paid. In turn, what is negative in the most general sense is the influence of construction on the natural environment and its resources. Urban areas use $1 / 3$ of all water (more than $35 \%$ according to the $\mathrm{EU}$ ). There is thus a need to make the public aware of the benefits of a joint approach to multi-family housing construction for the renewability of resources.

Widespread understanding of the "drop to drop" concept represents a proper direction towards more systematic economising on water. With this idea, waters not previously quantified (e.g., water and wastewaters from households) are treated as useable resources, representing an additional element among the renewable sources of water. Each user may have the impact of reducing small-scale retention, given that more than $70 \%$ of their property on average is no longer a biologically active surface capable of playing an active part in the cycling and retention of green waters through increased evaporation and evapotranspiration. 
From the point of view of the macro-use and non-renewable consumption of all water resources, the water management balance can be a monitoring tool to track various objectives and priorities (municipal, industrial, agriculture, forestry, or fish-farming, wherein both blue waters and green waters are used).

To increase amounts of green water needed by Poland's agriculture and horticulture as in the Netherlands, grey water, derived from the discharge of groundwater and somewhat-polluted surface runoff into watercourses, can be used. During the growing season, crops are irrigated with water resources more available and less costly than potable water.

Most forecasts indicate that the greatest future use of water will be in agriculture. If cultivated plants have sufficient water, then the overall increase in yields will depend on the potential transpiration, and hence the rate of conversion of water into water vapour. The demand exerted in this context during the growing season varies from species to species. Water management seeks out the best solutions in relation to species achieving ever-greater yields, or amounts of fresh or dry biomass. Yields will be higher the greater and more stabilised the humidity of soil. An example is supplied by yields per hectare in relation to permissible variations in humidity. Generally speaking, the water used in agriculture (be it grey, green or blue) is almost $100 \%$ irretrievable as a resource, being liberated by plants via the stoma and passing to the atmosphere, thanks to the processes of interception, transpiration, guttation, and dew formation.

Work by Łabędzki et al. (2010, 2014) shows that precipitation totals and distributions during the growing season (for sugar beets, for example), with a two-month time lag, determine the relationship with soil moisture, though each crop reacts to water amendments at a different rate. As Chapters 4 and 5 showed when dealing with the description of hydrological processes, reference should be made to the mid-1970s, when about $70 \%$ of water used $\left(8,101,300,000 \mathrm{~m}^{3}\right)$ went to industry, with the municipal management in second place at about $17 \%)$. That left only $13 \%$ for agriculture at the time.

Subsequently, marked changes in these proportions were planned with agriculture receiving the largest share. Plant species differ in how they use water to produce biomass, typically using about $200 \mathrm{~g}$ of water to produce $1 \mathrm{~g}$ of dry mass; the amount can be much greater: up to $1,000-1,500 \mathrm{~g}$ for some species. Thus, there has been a search for less thirsty crops, given the progressive water deficits that have been observed. This need is all the more relevant given the inevitability of human population growth, which will demand further increases in yields and harvests, all naturally at the cost of water used.

Drought during the growing season is a major problem that extends beyond the hydrological realm into the economic and ecological domains. Things are only likely to get worse as precipitation anomalies seem to worsen, with the direct result of a potentially disrupted hydroclimatic balance. The negative impacts of water deficits on soil and plants (and rivers and superficial sources of groundwater) can threaten crop yields, reducing them by more than $25 \%$. In turn, retention in a given area may reach a critical state (Kasperska-Wołowicz, Łabędzki 2003; Łabędzki et al. 2010).

Agro-climatologists also adopt a standardised climatic water balance as a measure of shortfalls in water supply, (termed $K B W$ in Polish) as was noted above (after Łabędzki 2003; Łabędzki, Adamski 2010; Wibig 2012; Wypych, Kowanetz 2017). This measure is based on standardised precipitation and soil humidity, capable of being described in various ways, e.g., empirically similar to the model arrived at by the French climatologists Turc and Pike (1964 after: Dooge 1982). As verified in the northern Sahara, this holds that:

$$
C W B=\sum P_{r}-0.4 t+15^{-1} I+50
$$

where: $\sum P_{r}$ is the total for corrected monthly precipitation totals [in $\mathrm{mm}$ ]; $t$ is the mean monthly value for air temperature $\left[{ }^{\circ} \mathrm{C}\right]$; and $I$ the monthly total for overall 24-hour solar radiation [expressed as calories per $\mathrm{cm}^{2}$ per day].

The time scale of saturation at which drought in the soil can develop is 1-3 months, after which hydrological drought ensues, possibly persisting for several months or even years. Wibig (2012) estimates the variability in soil-humidity conditions by reference to the Standardized Precipitation Evaporation Index (SPEI). It is recommended that evapotranspiration be represented as a function of potential evaporation (after Thornthwaite, Mather 1957; or Penman 1956). Humidity is then classified in relation to SPEI by reference to 9 intervals for $C W B$ values, reflecting the difference between the mean corrected precipitation total $\left(P_{r}\right)$, and the mean total for potential evapotranspiration $\left(E_{p}\right)$, also known as indicative evapotranspiration (in $\mathrm{mm}$ ), with:

$$
C W B=P_{r}-E_{p}
$$

Use is also made of heat-balance equations, with net radiation determined, along with all the component parts (heat fluxes), as calculated in Equation 4 above. CWB assumes positive or negative values, the latter indicating drought during the course of the hydrological year. Persistent shortfalls of water resources in agriculture are likely to become increasingly evident. $C W B$ values, and hence climatic shortfalls in precipitation, depend on the method applied in calculating indicative evapotranspiration $\left(E_{p}\right)$. An absolute assessment of the water involved in plant production may be achieved by reference to the difference between precipitation and evapotranspiration.

In summary, users of both real and virtual water are not just the population, or industry, or farming; but also include forests and nature. This truth clearly influences the cycling of water in drainage basins, and can be used effectively by those seeking to determine a balance for water retention that takes in both quantitative and qualitative aspects of the resource. What is involved here is a conscious steering of the water-balance structure in agricultural areas in relation to the uses of surface water and near-surface groundwater. Waters of good quality lying at greater depth, and only marginally renewable, should in turn be the subject of special, permanent protection.

\section{THE RENEWABILITY OF WATER RESOURCES AND THE IMPACT \\ OF CLIMATIC WARMING}

Fluxes of water and heat through the soiland-plant column and the drainage basin are subject to the influence of climatic conditions that are inter alia shaped by the chemical composition of the atmosphere, which regulates heat (and therefore energy) exchange processes. These processes themselves change at various rates because of rising emissions of greenhouse gases, which are associated with greater use of energy from burning fossil fuels. Deforestation, the intensification of farming, the activities of industry, and the transportation sector are all contributing to greenhouse gas emissions and climate change. 
As indicated beginning in the early 1980s by various leading scientists, climate change is undoubtedly influenced by the anthropogenic factors referred to, as official reports from the IPCC (e.g. in 2013 and 2014) make clear. This fact has gained confirmation empirically, despite opposition from some people in various countries.

As Dooge (1982) stated, the influence of global climatic warming opened a key stage in the development of a new and crucial area of hydrology. It provided a kind of "rejuvenating elixir" for disciplines engaged in the study of water(s), as well as for the closely related fields of meteorology, geodesy, cartography, and geophysics. Here, simultaneously, was a great methodological catalyst, especially where mathematical modelling was concerned. The integration of Earth-sciences disciplines was developing around a matter as crucial as the continued existence of the human species (as well as other species), and although naturally renewable, water was obviously one of the critical factors.

The linking of Global Circulation Models (GCM) scenarios with hydrological models of drainage basins requires the application of methods for mathematical rescaling of the transition of semi-empirical methods from data of low temporal and spatial resolution to high-resolution data (Kaczmarek 1996; Gutry-Korycka 1996; Lenartowicz, Gutry-Korycka 2009), etc. The confirmation of the influence of global climate change on hydrological systems was essential on both the mesoscale and the regional scale. However, the rates and directions of the changes involved may be related to different processes in different ways. Matters exerting an influence here include model precision, methods of estimation, and the measurement data used in projections for determining as realistically as possible the probable changes in system dynamics (IPCC 2000, 2007, 2012, 2014).

Among those addressing such issues were Gleick (1987), Ojima (1992), Lettenmaier (1994), Kaczmarek (1996) and Gutry-Korycka (1996). They all drew attention to the crisis facing water, given assessments suggesting major changes in resources. Such findings offered both impulse and inspiration for digital models of global climate to be developed, with spatially-dispersed or clustered parameters, and a possibility of achieving more and more accurate longterm forecasts (with development scenarios for the economy generated ever-more effectively). Thesemodels benefitted from new digital methods, multidimensional computer graphics, areal and satellite imagery of finer and finer resolution, etc. With measurement data being obtained with ever-greater precision, regional scenarios taking shape (with their "sub-scaling methods"), deterministic or stochastic drainage-basin models can be verified with respect to precipitation and outflow, and inter alia the water balance and/or climate-related aspects.

The advances in knowledge have been proving exceptionally valuable, while mathematical modelling has become more and more reliable, with operative versions now suitable for use in the forecasting of processes occurring on various scales.

Quantitative and qualitative assessment of changes in the proportionality between different forms of retention and river outflow were measures of what consequences global warming of the atmosphere was having for water resources. The ongoing developments in this field were thus very much targeted and fully justified in substantive terms. Often what were involved were regions and basins already poor in water resources, with the consequence that they might be particularly vulnerable to changes in water cycling. As levels of solar radiation increase, and along with them the temperature and humidity of the air, there must be a reduction in the magnitude of water resources and their availability, and hence also no guarantee that water will be available at all. However, in the circumstances of a changing climate, this kind of assessment is not an easy task, because water within each area, region or basin is in constant circulation. That means that the reserve available at any given moment is actually in a constant state of flux. Amounts of water in circulation determine the size of the renewable resource. The first measure of this quantity adopted was the long-term (multi-annual) mean obtained for total amounts of precipitation falling in given years. In contrast, the mean expressed on an areal basis has tended to involve the long-term river discharge, or else has been seen from the point of view of the water-management balance in which there is a description of characteristics of resources as: average or low, disposable, inviolable, guaranteed or other, from the point of view of the demand for economic use.

The first attempts at numerical simulation were made in the USA, Canada, Europe, Australia, and Japan at the end of the 1980s. They showed that as a consequence of global climatic warming renewable water resources during warm seasons might become $15-30 \%$ smaller than in the baseline period, while those in cool seasons might increase at various rates. Given the increased demand for water imposed by the economy, urbanisation, agriculture, livestock rearing, drainage, irrigation, the power industry, other industry, and construction, per- manent or at least periodic shortages of water would be implied.

Numerical simulations (of either the equilibrium or dynamic types) that can be used to assess changes in renewable resources of flowing water arise from combining Regional Global Circulation Models $\left(\mathrm{GCM}_{\mathrm{R}}\right)$ with a hydrological model of the conceptual type in which spatially-clustered or dispersed parameters describing processes are represented physically and $\mathrm{dy}$ namically with an appropriate time-step, along with an adopted scenario for economic development. Generated fields for air temperature, atmospheric precipitation, heat-balance components, field evaporation, and evaporation from the surfaces of open water reflect the circumstances in a meso-scale area that is the subject of analysis, in the form of spatial breakdowns that are set against long-term (20- or 30-year) reference means adopted as stationary values. However, this condition is not always met.

In the context of mathematical modelling what can be addressed are not merely shortages, but also surfeits, of water in the form of peak high-water events of increasing regularity or height, induced by precipitation, by a combination or precipitation and thawing, or by stormwater flows.

Circumstances of the inadequate or excess presence of water resources are perceived in the context of the threats to civilisation they potentially pose. Thus, these deviations from norms have often become the centre of attention nationally or internationally at too late a stage, especially for those who are actually using or managing the given water.

In the context of this article, there is a need to review the historical background, in order to understand the developmental stages that have been experienced. Many problems, which were once novel, now underpin contemporary understanding of mechanisms and global climatic processes, as well as the means of adaptation, albeit under economic conditions that remain as yet unknown.

So, what are, and what will be, the responses of hydrological systems to future global changes? If humankind elects to ignore the problem (as is hinted at) then catastrophe awaits our planet. Renewable resources of water (including groundwater) are already declining, with droughts and heatwaves increasing in scale and frequency, while both soil humidity and precipitation totals are in decline.

The causes of increases in the Earth's temperature (and hence premises underpinning climatic warming), have been of interest to geo- 
physicists for almost 200 years. This view is according to Malinowski (2019), though it was not confirmed by Biswas (1970), who nevertheless referred to the French mathematician and physicist Fourier (1719), with his collection of temperature data. This work may be treated as a precursor to the discovery of the mechanism underpinning the Earth's energy balance, as well as the way in which it may be assessed. In practice, however, about 150 years would pass before the issue was taken up by Anglo-Irish natural philosopher Tyndall, who noted the key significance of $\mathrm{CO}_{2}$ as a greenhouse gas, while also referring to methane and water vapour.

It is also worth citing the views of Belgian scientists at the University of Liège, Spring and Roland (Demarée, Verheyden 2016). In 1896, these authors were cited by Arrhenius. They were interested in emissions of greenhouse gases to the Earth's atmosphere. In addition to $\mathrm{CO}_{2}$ and water vapour, infra-red radiation is absorbed as a result of a rise in equilibrium temperature. Of course, were there to be no natural greenhouse effect, life on Earth would not be possible at all; this was something that Arrhenius did indeed refer to, having discovered it at the same time as the ozone layer. Moreover, at the end of the $19^{\text {th }}$ century it was shown that concentrations of $\mathrm{CO}_{2}$ were continuing to rise as a result of the burning of fossil fuels. This finding formed a basis for the estimation of changes of temperature $(\Delta t)$ on Earth as more or less given by $\pm \Delta \mathrm{CO}_{2}$. Continuing with this thread, it is important to recall the American physicist and astronomer Langley, who studied the transfer of sunlight and infrared radiation through the atmosphere at high latitudes. Malinowski (2019) made the connection to polar or Arctic strengthening of the greenhouse effect. In the 1930s, the British physicist Callendar was a pioneer in explaining how temperature in the atmosphere might rise in connection with the increased concentration of $\mathrm{CO}_{2}$ in the air.

Much later, American research on the isotopic composition of $\mathrm{CO}_{2}$ in the atmosphere, as well as the oxygen present in ocean sediments and ice cores, confirmed the dependence on the burning of coal and other fossil fields, which was directly responsible for atmospheric concentrations. Earth's sensitivity, even to limited climate forcing, is great, while disturbances and their effects expand, up to the planetary scale.

To sum up, global warming continues, and scientific uncertainty about changes in renewable resources of water is ever greater, given the dynamic configuration that the climate system represents. Re-expressing these kinds of problems as the economic costs of causes and effect, Stern $(2006,2019)$ expressed the view that net global emissions of greenhouse gases must fall to zero by 2050 , to prevent air temperature rising by more than $\approx 2^{\circ} \mathrm{C}$. Management of water resources was then assigned fifth place among six sectors of the economy crucial to the achievement of sustainable infrastructure development. These are, in rank order, power supply, urbanisation, food production, land use, water management, and industry. Integrated together, since 2018 these sectors form a new concept of macroeconomic activity known as the New Climate Economy. Water resources obviously play a key role.

\section{A NATURE-BASED SOLUTION (NBS) CONCEPT FOR WATER RESOURCES}

The historical review of the development of science, as well as contemporary activity and international climate policy offers the key challenges for programmes dealing with water and water resources (Section 3). Shortages or periodic excesses of water are among the threats to civilisation posed by the natural environment, though a quasi-equilibrium state of the Earth is still maintained (Falkenmark, Rockström 2004; Huntington 2010 et al.). Key resources are those of water and food, as well as biodiversity at the levels of the species or ecosystem. Given the temporal dynamics of phenomena in the environment, as well as causes and effects, it is anticipated that there will be changes over a longer time period extending to 2030, 2050, or even 2100 .

Two pyramids (as in Fig. 6) represent the virtual division of the world into two (northern and southern) parts, which differ across seven factors (i.e. the age of society, level of wealth, resources, type of influence due to climate change globally, technologies, and research), as well as features of the world's sustainable development in line with scales of development ranging from the local to the global (Sustainability Science 2001).

Lewis (2012) used an edition of Nature to justify and account that, given the presence of climate change, we should soon be needing an expanded network serving the interests of planetary research, to include problems associated with various aspects of water resources.

However, international organisations like the UN, UNESCO, ICSU, UNEP, WHO, IGBP, FAO, IPCC, FUTURE EARTH and others have based their long-term forecasts for resources on the period extending to 2050 .
Recent (2013 and 2014) IPCC reports make reference to Rockström et al. (2009), Rockström and Falkenmark (2014), Vörösmarty et al. (2010, 2013), and Steffen et al. (2015), expressing the growing risk that the Earth's capacity might be exceeded through excessive consumption of water, by what can be regarded as non-economical use of that resource, and the destruction in both qualitative and quantitative terms of the natural environment, including plant cover, soil, and even geological structure.

In light of these concerns, it has proved possible to identify sustainable routes to development, as well as barriers that should not be crossed. Many researchers, including Gallopin (2012), Cosgrove and Cosgrove (2012), Bierkens (2015) and Steffen et al. (2015) warn against excessive consumption and use of water resources. Moreover, an accelerating process of global climatic warming overlies the hydrological cycle, prevailing over all its components. Meanwhile, the limit of sustainability for water resources has not yet been crossed, notwithstanding the ever-growing risk that shortages will arise; on the other hand localised problems with excess water can be observed as ice, glaciers, and snow melt, and as flood events, intensify, not least on account of higher precipitation totals.

In applied science, recent years have seen an opening-up of new possibilities by which water deficits may be limited, accelerated, delayed, or contained both spatially and temporally. The use and management of water in urban and rural areas to try and economise has had further influence, in the appearance of a new area of knowledge (i.e. "Nature-based solutions") advocated by the last UNESCO International Hydrological Programme Report (NBS 2018).

The balancing of water resources available for use may prove helpful during a period of deficit, when it becomes imperative to incorporate mechanisms of directing processes of mass and energy exchange, in particular with losses of water brought about by planted vegetation or that growing naturally (Veldkamp et al. 2015). This balance requires linking identified resources and needs for water arising from the economy, as well as management within the framework of land-use planning that references the main economic, political, and social considerations. Integrated management of resources is especially important in urban and industrial areas, including the building, redeveloping or revitalising of stormwater drainage, with the aim 
of the infrastructure not merely moving water but also supplying capacity for its retention. Most generally, it is essential that outflow from impermeable surfaces like roads and pavements should be redirected, for example, by increasing the permeability of surfaces on squares, car parks, sports fields, etc. It is in this kind of activity that we see appropriate adaptation to climate change (Burszta-Adamiak 2015, 2018). Water management is far more effective, and far easier, where there is a centralised system serving this purpose. Rainwater runoff and water from melting snow and ice can in this case be transferred to reservoirs, and resources recouped by way of systems of transfer to artificial ecosystems set up in the immediate vicinity of buildings.

The 2018 report on NBS makes no mention of the potential for use of grey infrastructure and grey water. Thus, the following describes certain NBS directions and solutions for the use of water resources that enjoy that status on account of their being inspired by the laws of nature. In terms of broad scope it is green infrastructure that is being referred to, which is capable of operating in parallel, in a measurable and beneficial way, with grey infrastructure; where hydrological processes relating to the quantity and quality of water are integrated. The principal objective is to find the most appropriate linkage between grey water and green water, so that maximum benefit can be drawn from operating the system and its capacity, with costs minimised, and the number of components limited.

For an example, we may refer to a model for irrigation by means of the optimisation of efforts to achieve harmony (Čistŷ 2008) in the operation of irrigation systems. Work by Kovalenko and Mikhaylov (2008) relates to the control of irrigation in a system, under conditions of minimised uncertainty of supply.

It needs to be added that, for example, the temporal and spatial modelling of very variable agro-hydrological processes in a drainage basin often requires 24-hour meteorological measurement data; the lack of these data precludes necessary simulation and forecasting in the service of decision-making (Kuchar 2004).

The latest NBS generate environmental, economic, and social benefits relating to the use of water resources, especially in terms of health and sanitation, as well as food, water, and energy security. These ideas promote economic growth while maintaining biological diversity,

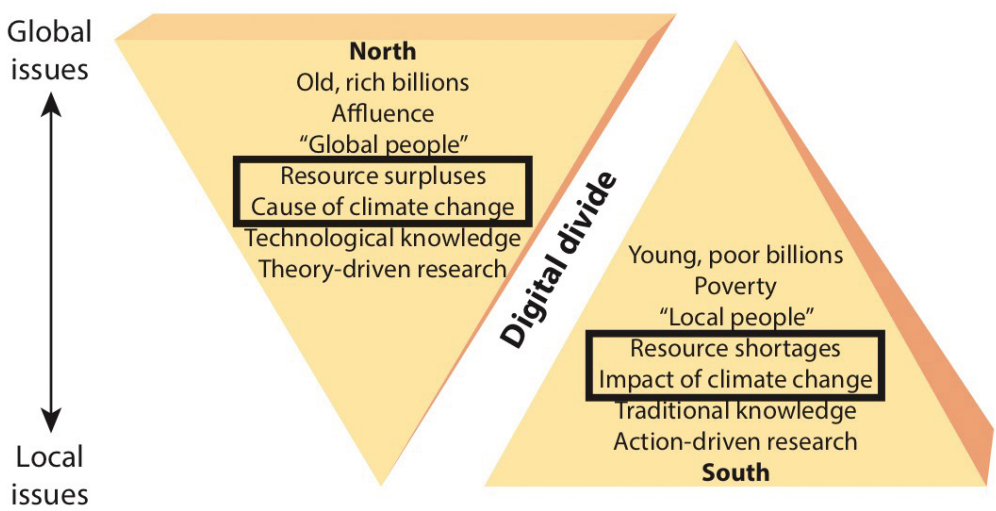

Fig. 6. Sustainability science within a divided world (Science 2001, vol. 292, No 5517, p. 641-642; boxes added by the author)

and the recovery of species at risk for extinction, leading to the protection of whole ecosystems

As opportunities for NBS to be applied are sought, reference will need to be made to the fulfilment of principles set out in the UN's (2014) Declaration on Water. The assumption is that each Member State is obliged to increase water resources through natural renewability, with efforts also made to achieve improvements in water quality, and long-term sustainability of use. For their part, EU Member States have been called upon since 2011 to rapidly and permanently achieve sustainability vis-àvis resources of water (and the ecological state thereof), above all through consumption that is adjusted to ensure many different sectors of the economy can have their demands met.

Particularly noteworthy are the conceptions for water management in EU Member States set out in the Framework Water Directive, and thus upheld by both the European Parliament and the European Environment Agency. NBS that govern the hydrological and hydroclimatic cycle should be able to supply economic, social, and ecological benefits that provide for the optimal utilisation of water in line with the needs of food, energy, and sanitary security.

The use of green and grey water in connection with suitable infrastructure makes savings possible, translating into accelerated renewability of resources, with consequent knock-on effects for financing as well.

In United Nations World of Water Development Report (2018), examples of NBS in the form of theoretical curves have been selected carefully enough to ensure the representation of benefits, above all quantitative ones concerning renewable resources in connection with longterm economic benefit. These curves appropriately correspond to actions taken, with one such presented in Figure 7 showing changes in an ecosystem's throughputs of matter and energy.

Considerable potential for NBS-type ideas can be found in references to regionalor local-scale land use, as translated into the rate of change in water cycling around the shortbranch nexus (taking into account biomass increment, productivity, and evapotranspiration (Falkenmark 1989).

A dynamic water-management balance represents a proper basis for the quantitative management of water resources, for example, proving helpful in the phase of early warning and implementation, as well as facilitated decision-making for the sustainable use of resources

Major opportunities for benefit lie in assessments of adaptations to global change where the rate and direction of change in the hydrological cycle are concerned. Post-2015 there was a particularly lively debate on the significance of water for the Earth's future. In turn, the world scientific programme Future Earth existed alongside the UN and other international organisations. Most recently (in February 2019), Japan organised the world Ecological Forum in Tokyo.

Identified among the key topics for discussion at the Tokyo Forum were food security and the depletion of natural resources (including water). The aim was to bring together representatives of academia and business, industrialists, citizens, and students. The discussion centred on solutions that might prove effective and could be implemented rapidly, in this way serving the achievement of sustainability in nature and society. A Forum was devoted to the main aim of the Global Environmental Facility, said to have "Clearly stated stewardship over the Earth in the Anthropocene Era and introduced the concept of Global 
Commons (United Nations World of Water Development Report 2018).

Nakamura from Hokkaido University demonstrated the recovery process in the Japanese environment by reference to many images, while also introducing how useful green infrastructure might prove in preventing natural disasters (floods of various kinds, tsunamis, droughts, etc.). Finally, there was a presentation of a relevant Programme within the International Global Environment Sustainability (IGES) framework.

The involvement of interested parties in seeking to achieve permanent infrastructural solutions in this field requires a transformation, or totally new approaches and challenges.

\section{CONCLUSIONS}

\section{AND REMARKS}

In summary, existence in the longer term will be very much supported by the integration into economies of construction, industry, spatial planning, and the management and protection of water resources whose renewability is assured by effective conservation and limitations on levels of stress.

As with the biological approach, a broad framework of designated tasks has been adopted in line with a definition whereby the IUCN considers NBS as »actions to protect, sustainably manage, and restore natural or modified ecosystems, that address societal challenges effectively and adaptively, simultaneously providing human well-being and biodiversity benefits" (United Nations World of Water Development Report 2018).

If designated tasks are to be pursued effectively, there is a need for close cooperation, major financial outlays, efficient management, and most of all an awareness and understanding on the part of societies that solutions such as NBS are justified in the interests of the Earth's future, focusing on renewable resources and efforts to ensure their regeneration; which is to say a return to sustainability (for the benefit of future generations as well as ours). As a key barrier to development, water resources have recently been going through quite a crisis. That makes it important for integrated solutions to be adopted to limit negative environmental impacts, in regard to both the quality and the quantity of water. Appropriate decision-making is very much dependent on scientists' clear identification of environmental processes that play a key role in upholding renewability of use, as well as the minimising of barriers on the global, regional, and local scales.
Contemporary knowledge and technological progress, involving ICT in general, and mathematical modelling in particular, support several key tasks. Appropriate, optimal methods and solution-oriented functions need to be found, in order that many processes responsible for current changes may be assessed. And thus, it is water, present in various states in all the spheres that is of priority significance! The management of water resources in the context of urban and rural governance must limit or ameliorate negative social and environmental impacts.

Ultimately, NBS methods need to be approached with caution, separately for quantities of water resources dependent on hydrological processes, but also with respect to water quality and the processes of geochemical pollution integrated with it. Although this article does not include solutions applied in biomanipulation that resort to ecohydrological measures, these do exist.

Austrian geochemists like Weigelhafer et al. (2013) stress how necessary it is for the possibility of NBS being considered for approaches to water resources, both for quantity and quality, with limited use, for example, being made of retention.

Sectoral accessibility of water resources achieved sustainably (and hence with ongoing renewability assured) represents a key challenge needing to be integrated with a legislative approach, governance at various levels, and executive action. The quality of water resources and simultaneous improvement in the state of ecosystems dependent on water represent matters for NBS, and they need to be addressed in an integrated fashion. Legal bases are required to achieve these outcomes, but they also require ongoing hydrological and biological monitoring of waters in a near-natural state, so that the changes and benefits achieved may be assessed. NBS methods can be seen in the context of risk assessments, with the aim being to ensure maximum effectiveness (Fig. 6), but also in the context of inevitable adaptation to global change. Effectiveness in the specific context of reduced maximum flows along watercourses should represent a multidimensional function of intervention resulting from impacts of decision-making in such critical circumstances. UNESCO, in fact, appeals to each Member State to gain regional and local experience of what may be implemented in different basins, leading to cohesive spatial management plans in line with guidelines of the NBS type.

A very important aspect is, of course, the funding of planned solutions set against the background provided for in legislation, again with the aim of harmonious cooperation proceeding in different sectors seeking to achieve their aims. Pursuit of NBS to protect water resources should entail precise definition of the potential for goals and objectives to actually be achieved, with information provided current conditions and the problems still needing to be resolved, i.e. if Agenda 2030 guidelines are to be more fully realized.

The UN has among its key objectives the division of the world into two groups (Fig. 6), as well as seamless supply water to humankind and the economy, with each citizen enjoying access to water supply and sanitation services, and with efforts also made to reduce and limit the risk of natural disasters like floods and droughts. The role of ecosystems in linking new infrastructural developments with proper management lies in the way we seek to imitate the laws of nature more and more faithfully, given that this is a condition if continuity over the long term is to be assured. And in the future, key activities will entail restoration of much-degraded aquatic or semi-aquatic ecosystems to a natural state, inter alia for their utilitarian and intrinsic values.

A key element connected with the above aim is the redevelopment and restoration of grey infrastructure, requiring a remodelling of agriculture and redevelopment of its systems of irrigation and drainage. The reduction of conflicts between competing interests and business by way of the application of different categories of water resources is a utilitarian step in this direction. Actions to conserve and avoid wasting of water in rural, urban, and industrial areas should also be seen as very pragmatic. Green and grey infrastructure in place can do much to lower costs of water use, while limiting the optimal use of resources of grey and green water.

Efforts to manage the risks associated with, or safeguard against, floods or states of low water should also prioritise the reduction or indeed minimisation of costs. Green and grey infrastructure can combine with an economy operating in closed cycle to markedly improve NBS, in urban areas in particular; while the uncertainty surrounding integration with grey and green infrastructure in rural areas may prove more difficult (yet still a necessity). It should be added that the latest UNESCO IHP Report (from 2018) presents the most major and most effective regional examples of NBS seeking to reduce maximum flows in the cases of floods likely to occur every 20 years on average, and to limit 
leading factors promoting change. These examples include Green Cities in the UK, countries in the Baltic basin and northern Adriatic; northern Italy, Poland, and Scandinavian countries other than Denmark (reintroduction of river paleo-meanders along larger rivers); western France, Spain, Portugal, central and southern Italy, Denmark, Greece, Romania, Hungary, Bulgaria, southern Austria and Switzerland, as well as southern Germany (forecasting development of agricultural practices). In contrast, in NE Germany, the Benelux, northern Austria, the Czech Republic and Slovakia it is re-afforestation that is stressed; along with the development of polders in NE and N France, the Benelux and western Germany.

In line with the relevant planning, the objectives set and effective changes foreseen have a very significant financial dimension. High implementation and maintenance/operating costs translate into fees and taxes, and there will need to be special subsidies at the local, central and EU levels. Legislative provisions and authorising regulations are both essential to this kind of activity, while inter-sectoral cooperation is foreseen, or has already taken its proper place in provisions of the EU's Water Framework Directive.

The humanitarian aspect of water resources also makes it imperative that waters are protected and limits imposed, globally, regionally, and locally. These needs reflect a predicted increase in the use of water of some $20-30 \%$ (5,500-6,000 $\mathrm{km}^{3}$ per year) by 2030. Further growth will be a function of ongoing agricultural development to safeguard food supplies and the availability of water for use in sanitation, for drinking, and for energy generation transportation.

The priority actions and solutions relating to water thus follow the concept of recycling, reuse, restoration, recovery and risk reduction, as well as improvements in quantity and quality, and effective regional-level management where implementation is concerned.

Adaptation of resources in line with the NBS concept is needed, not only to improve water management, but also to safeguard water to some critical level in the context of shared benefit. The NBS return of water resources to nature is not a panacea for everything, however, and the directions indicated here represent a long and hard road to the achievement of a desirable future situation.

Moreover, the environmental and social aspects will need to be clearly communicated and justified in the context of planned solutions and legislation, as well as management in the direction of diversification.

In sum, there is still a need to consider the directions taken and the progress made around the world in achieving stated objectives, which are based on awareness of joint action under the Earth System Science Partnerships (ESSP), Earth Environmental Science (EES), World Resources and Environment (WRE) and "Partnerships are key to success in the Future", as adopted by the UN, World Climate Research Programme (WCRP), Earth WHO, the Club of Rome and Vatican World ... 2013, and Laudato Si of 2015), as well as many other documents and scientific papers (Couwe 2009), plus works published to popularise the idea.

The new trends in hydrology, water management, hydroengineering and technology will become elements of contemporary science and practice.

Efforts to explain the causes and effects of contemporary development demands inter-disciplinary or trans-disciplinary approaches. It will be necessary to continue with forecasting dynamic processes of water circulation, as these operate on the global, continental, regional, or local scales. For these goals to be achieved it is important that there be widespread awareness of choices, confidence on the part of society, and an identification of critical points (or indeed tipping points) relevant to geophysical, biochemical, biological, and economic systems in a multidimensional configuration, with water resources connected to the regularities that govern their renewability.

For life on Earth to survive, it is necessary that the crisis surrounding water resources be addressed to the extent possible. It is known that about 2.5 billion of the world's people live in areas that are poor in water resources; while long-term forecasts (only in fact extending to 2030) suggest that we will experience a decline in the availability of water of $\geq 40 \%$. If present trends are maintained, they imply a 2050 situation in which more than half of the human population will face the threat of permanent deficit of fresh water resources. Thus, there is a clear imperative for actions that will reduce this risk. Can the situation involving unsustainable management of water resources somehow be turned around? Certainly, it will be difficult to achieve, if even possible, given that widespread awareness, combined with knowledge and experience, will be essential.

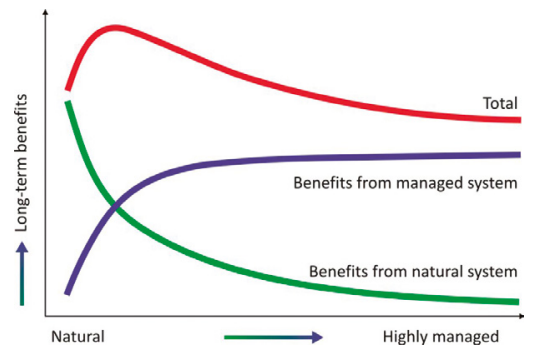

Fig. 7. Change in benefit flows with ecosystem modification (based on Acreman 2001)

The NBS concept developing currently may be understood in two ways: as nature for water, and as water for nature. In both cases, the beneficiaries are water resources, curtailed shortages and deficits, and hence enhanced protection.

\section{ACKNOWLEDGEMENTS}

Finally, the author would like to thank Prof. Dr Janusz Kindler from Warsaw University of Technology in Poland, Prof. Dr Henry Van Lanen from Wageningen University in Netherlands for their help in support and providing constructive and critical feedback which helped to improve the quality of this paper.

What is more, I would like to express my gratefulness for support in editing this article.

\section{REFERENCES}

- Acreman M., 2001, Ethical aspects of water and ecosystems, Water Policy, 3 (3), 257-265, DOI: 101016/S1366-7017(01)00009-5

- Barry R.G., Chorley R.J., 2003, Atmosphere weather and climate, $8^{\text {th }}$ edition, Routledge, London-New York, 464 pp.

- van Bavel C.H.M., Hillel D.I, 1976, Calculating potential and actual evaporation from a bare surface by simulation of concurrent flow of water and heat, Agricultural Meteorology, 17 (6), 453-476, DOI: 10.1016/0002-1571(76)90022-4

- van Beek L.P.H., Wada Y., Bierkens M.F.P., 2011, Global monthly water stress: 1. Water balance and water availability, Water Resources Research, 47, W07517, DOI: 10.1029/2010WR009792

- Bennett G., Nathaniel C., Hamilton K., 2013, Charting new waters: State of watershade payments 2012, Ecosystem Marketplace, available at https://www.forest-trends.org/wp-content/ uploads/imported/state-of-watershed-payments-2012_1-22-13_web-pdf.pdf (data access 02.07.2019)

- Bierhuizen J.F., Slatyer R.O., 1965, Effect of atmospheric concentration of water vapor and $\mathrm{CO}_{2}$ in determining transpiration photo- 
synthesis relationships of cotton leaves, $\mathrm{Ag}$ ricultural Meteorology, 2 (4), 257-270, DOI: 10.1016/0002-1571(65)90012-9

- Bierkens M.F.P., 2015, Global hydrology 2015: state, trends, and directions, Water Resources Research, 51 (7), 4923-4947, DOI: 10.1002/2015WR017173

- Biswas A.K., 1965, The hydrologic cycle, Civil Engineering, 35, 70-74

- Biswas A.K., 1970, History of hydrology, North-Holland Publishing Company, Amsterdam, 336 pp.

- Biswas A.K., 2004, From Mar del Plata to Kyoto: an analysis of global water policy dialogue, Global Environmental Change, 14, (Supplement), 81-88, DOI: 10.1016/j.gloenvcha.2003.11.003

- Brown A., Matlock M.D., 2011, A review of water scarcity indices and methodologies, The Sustainability Consortium, White Paper No 106, available at https://www.sustainabilityconsortium.org/downloads/a-review-of-water-scarcity-indices-and-methodologies/?wpdm$\mathrm{dl}=17776$ \&ind $=1502195885322$ (data access 02.07.2019)

- Budyko M.l., 1977, Global'nauka ekologiya, (in Russian), Mysl' Publishers, Moscow

- Budyko M.I., 1986, The evolution of the biosphere, Springer Netherlands, 424 pp.

- Burek P., Mubareka S., Rojas R., De Roo A., Bianchi A., Baranzelli C., Lavalle C. and Vandecasteele I., 2012, Evolution of the effectiveness of Natural Water Retention Measures: Support to the EU Blueprint to Safeguard Europe's Waters, Publications Office of the European Union, Directorate-General Joint Research Centre, Institute for Environment and Sustainability, DOI: $10.2788 / 55280$

- Burek P., Satoh Y., Fisher G., Kahil M.T., Scherzer A., Tremberend S., Nova L.F., Wada Y., Eisner S., Flörke M., Hanasaki N., Magnuszewski A., Cosgrove B., Wiberg D., 2016, Water Futures and Solution: fast track initiative, Final Report, IIASA Working Paper, Laxenburg, Austria, WP16-006, available at http://pure.iiasa.ac.at/id/ eprint/13008/ (data acces 02.07.0219)

- Burszta-Adamiak E., 2015, Zielone dachy jako element zrównoważonych systemów odwadniających na terenach zurbanizowanych, Uniwersytet Przyrodniczy we Wrocławiu, Wrocław, 124 pp.

- Burszta-Adamiak E., 2018, Zrównoważone gospodarowanie wodą w miastach, Eko-lokator Project, available at http:// zielonainfrastruktura.pl/eko-lokator-zrown- owazone-gospodarowanie-woda-wywiad-z-dr-hab-inz-ewa-burszta-adamiak-z-uniwersytetu-przyrodniczego-we-wroclawiu/ (data access 02.07.2019)

- Calder I.R., Hall R.L., Halder P.G., 1992, Growth and water use of forest plantations, John Willey and Sons, Chichester, New York, Brisbane, Toronto, Singapore, 381 pp.

- Cardwell D.S.L., 1965, Power technologies and the advances of science, 1700-1825, Technology and Culture, 6 (2), 188-207, DOI: 10.2307/3101073

- Casterson R., 1991, Conference final remarks, [in:] Water awareness in societal planning and decision-making, I. Johansson (ed.), Swedish Council for Building Research, Stockholm,

- Chapagain A.K., Hoekstra A.Y., 2004, Water footprint of nations. Volume 1: Main report, Value of Water Research Report Series No. 16, UNESCO-IHE, Delft, Netherlands, 77 pp.

- Chow V.T., 1964, Handbook of applied hydrology, McGraw-Hill, Book Co, New York, 1418 pp.

- Čistŷ M., 2008, Automated calibration of the simulation model of irrigation projects by harmony search optimization, Journal of Water and Land Development, 12 (1), 3-13, DOI: 10.2478/v10025-009-0001-1

- CoE, 1956, Snow hydrology: summary report of the snow investigations, United States Army Corps of Engineers, North Pacific Division Corps of Engineers, U.S. Army, 437 pp.

- Cosgrove C.E., Cosgrove W.J., 2012, The dynamics of global water futures: Driving forces 2011-2050. Report on the findings of Phase One of the UNESCO-WWAP Water Scenarios Project to 2050, WWDR4 Report, UNESCO, Paris, France, 95 pp.

- Couwie J., 2009, Zmiany klimatyczne, przyczyny, przebieg i skutki dla człowieka, Uniwersytet Warszawski, Warszawa, 452 pp.

- Craig J.R., Vaugham J., Skinner B., 2001, Resources of the Earth: origin, use and environmental impact, Prentice Hall, 520 pp.

- Czerny M., 2008, Koncepcja zabezpieczenia egzystencji podatności społecznej w rozwoju regionalnym, [in:] O nowy kształt badań W geografii w gospodarce przestrzennej, T. Stryjakiewicz, T. Czyż (eds.), Biuletyn KPZK PAN, 237, 171-185

- Da Cunha L.V., 1991, Water resources management in industrialized countries problems and challenges, [in:] Water awareness in societal planning and decision-making, I. Johansson (ed.), Swedish Council for Building Research, Stockholm, 69-86
- Dadson S.J., Hall J.W., Muratroyd A., Acreman M., Botes P., Beven K., Heathwaite L., Holden J., Holman I.P., Lane S.N., O’Connell E., Penning-Rowsell E., Reynald N., Sear D., Thorne C., Willby R., 2017, A Restatement of the natural science evidence concerning catchment-based natural flood management in the UK, Proceedings of the Royal Society A: Mathematical, Physical and Engineering Sciences, 473 (2199), DOI: 10.1098/ rspa.2016.0706

- Delamétherie J.-C., 1797, Théorie de la terre, vol. 4, ed. 2, Chez Maradan, Paris, 535 pp.

- Delang C.O., 2018, Local livelihoods and global processes: complex causalities in Hong Kong's Sai Kung Penisula, Miscelanea Geographica, 22 (1), 31-39, DOI: 10.2478/mgrsd-2018-0003

- Demarée G.R., Verheyden R., 2016, Walther Victor Spring - a forerunner in the study of the greenhouse effect at the University of Liége Belgium, Papers on Global Change IGBP, 23 (1), 153-158, DOI: 10.1515/igbp-20160011

- de Wit C.T., 1958, Transformation and crop yields, Institute of Biological and Chemical Research on Field Crops and Herbage, Wageningen, The Netherlands, available at: https://library.wur.nl/WebQuery/wurpubs/ fulltext/186445 (data access 05.08.2019)

- de Wit C.T., 1965, Photosynthesis of leaf canopies, Agricultural Research Reports No 663, Institute of Biological and Chemical Research on Field Crops and Herbage, Wageningen, The Netherlands, available at https://library. wur.nl/WebQuery/wurpubs/fulltext/187115 (data access 05.08.2019)

- de Wit C.T., 1969, On water and crops, Syllabus Lectures, IAC, Wageningen, available at http:// edepot.wur.nl/188477 (12.08.2019)

- Dictionary, 2001, Międzynarodowy słownik hydrologiczny, Wydawnictwo Naukowe PWN, Warszawa, 250 pp.

- Dobrowolski A.B., 1923, Historia naturalna lodu, Kasa im. Mianowskiego, Warszawa, 940 pp.

- Dobrovolski S.G., 1992, Global climate changes in water and feat transfer accumulation process, Elsevier Science Publisher, Amsterdam, 265 pp.

- Dooge J.C.I., 1959a, A general theory of the unity hydrograph, Journal of Geophysical Research, 64 (2), 241-256, DOI: 10.1029/ JZ064i002p00241

- Dooge J.C.I., 1959b, Un bilan hydrologique au XVIIe siècle, La Honille Blanche, 6, 799-807, DOI: 10.1051/lhb/1959063 
- Dooge J.C.I., 1974, The development of hydrological concepts in Britain and Ireland between 1674 and 1874, Hydrological Sciences Bulletin, 19 (3), 279-302, DOI: 10.1080/02626667409493917

- Dooge J.C.I., 1982, Hydrologic models and climate change, Journal of Geophysical Research, 97 (D3), 2677-2686

- Dooge J.C.I., 1984, Modelling the behaviour of water, [in:] Forest, climate and hydrology: regional impacts, E.R.C. Reynolds, E.B. Thompson (eds.), UNU Workshop, Oxford, March 1984, United Nations University, Tokyo, 128-161

- Drogers P., Immerzeel W., 2008, Managing the real consumer: evapotranspiration, Report Future Water No 78, available at https://www. futurewater.nl/downloads/2008_Droogers_ FW78.pdf (data access 05.08.2019)

- EC, 2011, Woda to życie. W jaki sposób ramowa dyrektywa wodna chroni zasoby wodne Europy, available at https://wroclaw.rzgw.gov.pl/ files_mce/Region\%20wodny/Planowanie/ wfd_brochure_pl.pdf (12.08.2019)

- EC, 2013, Report from the Commission to the Council and the European Parliament on the implementation of Council Directive 91/676/EEC concerning the protection of waters against pollution caused by nitrates from the agricultural sources based on Member State reports for the period 2008-2011, COM/2013/683final, EUR-Lex, Brussels

- EEA, 2012a, European waters - assessment of status and pressures, EEA Report No 8/2012, European Environmental Agency, Copenhagen, available at https://www.eea. europa.eu/publications/european-waters-assessment-2012 (data access 05.09.2019)

- EEA, 2012b, Water resources in Europe in the context of vulnerability, EEA Report No 11/2012, European Environmental Agency, Copenhagen., available at https://www.eea.europa.eu/publications/water-resources-and-vulnerability (data access 05.08.2019)

- EEA, 2018, Water is life. Europe's rivers, lakes and seas are under pressure from pollution, overexploitation and climate change. How can we ensure a sustainable use of this vital resource? EEA Signals, European Environmental Agency, Copenhagen, available at https://www.eea.europa.eu/ publications/eea-signals-2018-water-is-life (05.08.2019)

- Ericksen P., 2008, Global Environmental Change and Food Security, Global Change Newsletter, 71, 10-16
- Falkenmark M., 1983, Urgent massage from hydrologists to planers: water a silent messenger turning land use into river response, [in:] Scientific Procedures Applied to the Planning, Design and Management of Water Resources Systems (Proceedings of the Hamburg Symposium, August 1983), IAHS Publication No 147, 61-75

- Falkenmark M., 1984, New ecological approach to the water cycle: ticket to the future, Ambio, 13 (3), 152-160

- Falkenmark M., 1986, Fresh water - time for a modified approach, Ambio, 15 (4), 192-200

- Falkenmark M., 1989a, Climate Induced Hydrological Shifts in Europe and their Implication Spectrum, [in:] Conference on Climate and Water, Helsinki, Finland, 2, 43-67

- Falkenmark M., 1989b, Hydrological phenomena in geosphere-biosphere interactions: outlooks to past, present and future, IAHS Press, $96 \mathrm{pp}$.

- Falkenmark M., 1991, Water - the multidimensional resources. The predictable carrier of solutes and the active link to ecosystems, [in:] Water awareness in societal planning and decision-making, I. Johansson (ed.), Swedish Council for Building Research, Stockholm, 21-42

- Falkenmark M., Chapman T., 1989, Comparative hydrology: an ecological approach to land and water resources, UNESCO, Paris, 479 pp.

- Falkenmark M., Da Cunha L.V., David L., 1987, New water management strategies needed for the $21^{\text {st }}$ century, Water International, 12 (3), 94101, DOI: 10.1080/02508068708686589

- Falkenmark M., Rockström J., 2004, Balancing water for humans and nature. The new approach in ecohydrology, Earthscan, London, 320 pp.

- Feddes R.A., 1971, Water, heat and crop growth, Ph.D. thesis, Wageningen Agricultural University, The Netherlands

- Feddes R.A., Kabat P., van Bakel P.J.T., Bronswijk J.J.B., Halbertsma J., 1988, Modelling soil water dynamics in the unsaturated zone - state of the art, Journal of Hydrology, 100 (13), 69-111, DOI: 10.1016/0022-1694(88)90182-5

- Feddes R.A., Koopmansa R.W.R., van Dam J.C., 1997, Agrohydrology, Wageningen Agricultural University, Department of Water Resources, Wageningen

- Feddes R.A., Kowalik P.J., Zaradny H., 1978, Simulation of field water use and crop yield, Wiley, New York, 188 pp.

- Feddes R.A., Wind G.P., van Wijk A.L.M., 1980, Soil-plant-atmosphere systems, [in:] Research Digest, E.W. Schierbeek (ed.), Technical Bul- letin No 117, Institute of Water Management Research, Wageningen, 84-114

- Francis, 2015, Encyclical Letter Laudato Si' of the Holy Father Francis on Care for our Common Home, Vatican Press, Rome, 184 pp.

- Gallopín G.C., 2012, Five Stylized Scenarios, Series: Global Water Scenarios to 2050, UNESCO, Paris, available at https://unesdoc.unesco. org/ark:/48223/pf0000215380 (12.08.2019)

- Gartner T., Mulligan J., Schmidt R., Gunn J. (eds.), 2013, Natural infrastructure. Investing in forested landscapes for source water protection in the United States, World Resources Institute, Washington, $132 \mathrm{pp}$.

- Gash J.H.C., Shuttleworth W.J., 2007, Evaporation, IAHS Benchmark Papers in Hydrology Series, Wallingford, Oxfordshire, 526 pp.

- Gerten D., Rockström J., Heinke J., Steffen W., Richardson K., Cornell S., 2015, Response to comment on Planetary boundaries: Guiding human development on a changing planet, Science, 348 (6240), 12171217, DOI: 10.1126/ science.aab0031

- Gray D.M., Prowse T.D., 1993, Snow and flooding ice, [in:] Handbook of hydrology, D.R. Maidment (ed.), McGraw Hill Inc.

- Gleick P.H. (ed.), 1987, Water in crisis. A guide of the world's fresh water resources, Oxford University Press, Oxford, $504 \mathrm{pp}$.

- Gutry-Korycka M., 1993, Wpływ różnych form gospodarki na obieg wody, [in:] Przemiany stosunków wodnych w Polsce w wyniku procesów naturalnych i antropogenicznych, J. Dynowska (ed.), Wydawnictwo UJ, Kraków, 299-390

- Gutry-Korycka M., 1996a, Rola modeli hydroekologicznych w badaniach różnorodności biologicznej ekosystemów wilgotnych, Przegląd Geograficzny, 62 (3-4), 349-365

- Gutry-Korycka M. (ed.), 1996b, Studia nad wpływem globalnych zmian klimatu na obieg wody w zlewni, Wydawnictwo WGSR UW, Warszawa, 184 pp.

- Gutry-Korycka M., 2003, Możliwości modelowania odpływu ze zlewni zurbanizowanych uprzemysławianych, [in:] Człowiek i środowisko, PTG Katowice, Sosnowiec, 33-53

- Gutry-Korycka M., 2007, The heat cycle The water cycle and changes in land use, $\mathrm{Pa}$ pers on Global Change IGBP, 14, 39-53

- Gutry-Korycka M., 2009, Zobowiązania nauki wobec zrównoważonego rozwoju środowiska życia człowieka w warunkach globalnych zmian klimatu, [in:] Zrównoważone warunk życia w zmieniającym się systemie klimatycz- 
nym Ziemi, M. Gutry-Korycka, T. Markowski (eds.), Studia KPZK PAN, Warszawa, 8-18

- Gutry-Korycka M., 2017 A look at global climate change through Papal Encyclicals. Papers on Global Change IGBP, 24 (1), 53-65, DOI: 10.1515/igbp-2017-0005

- Gutry-Korycka M., 2018, Zasoby wód płynących Polski. Uwarunkowania, wykorzystanie, zmiany, IMGW-PIB, Warszawa, 117 pp.

- Gutry-Korycka M., Nowicka B. (ed.), 2003, Rola retencji zlewni w kształtowaniu wezbrań opadowych, WGiSR, Uniwersytet Warszawski, Warszawa, 207 pp.

- Gutry-Korycka M., Sadurski A., Kundzewicz Z.W., Pociask-Karteczka J., Skrzypczyk L., 2014, Zasoby wodne a ich wykorzystanie, Nauka, 1, 77-89

- Halley E., 1687, An estimate of the quality of vapour raised out of the sea by the warmth of the sun; derived from an experiment shown before the Royal Society, at one of their late meetings, Philosophical Transaction of the Royal Society of London, 16 (189), 366370, DOI: 10.1098/rstl.1686.0067

- Haimes Y.Y., Kindler J., Plate E.J., 1987, The processes of water resources project planning: a systems approach, Studies and Reports in Hydrology Series, 44, UNESCO, Paris, 196 pp.

- Huntington T.G., 2010, Climate warming - Induced intensification of the hydrological cycle: an assessment of the published record and potential impact of agriculture, Advances in Agronomy, 109, 1-53, DOI: 10.1016/S00652113(10)09001-2

- Hoekstra A.Y. (ed.), 2003, Virtual water trade, Water Research Report Series No 12, available at https://waterfootprint.org/media/downloads/Report12.pdf (data access 05.08.2019)

- Hoffman M., Johnsson H., Gustafson A., Grimvall A., 2000, Leaching of nitrogen in Swedish agriculture - a historical perspective, Agricultural Ecosystems and Environment, 80 (3), 277290, DOI: 10.1016/S0167-8809(00)00154-7

- Houghton R.A., Woodwell G.M., 1989, Global climate change, Scientific American, 260 (4), 36-44, DOI: 10.1038/scientificamerican0489-36

- Arnell N. (ed.), 1989, Human influences on hydrological behaviour: an international literature survey, Contribution to IHP Project 6.1, UNESCO, Paris, available at https://unesdoc. unesco.org/ark:/48223/pf0000095236 (data access 05.08.2019)

- IGBP, 1990, The International Geospher-Biospher Programme: A study of global change, IGBPReportNo12,Stockholm, availableathttp:// www.igbp.net/download/18.950c2fa1495db7081e1938/1430900165543/IGBP_report_12-Initial_Core_Projects.pdf (data access 05.08.2019)

- IPCC, 1995, IPCC Second Assessment. Climate Change 1995, A Report of the Intergovernmental Panel on Climate Change, available at https://www.ipcc.ch/site/assets/ uploads/2018/05/2nd-assessment-en-1.pdf (data access 02.07.2019)

- IPCC, 2008, Climate change and water, IPCC Technical Paper VI, B. Bates, Z.W. Kundzewicz, S. Wu, J. Palutikof (eds), Intergovernmental Panel on Climate Change, Geneva, 200 pp.

- IPCC, 2012, Managing the risk of extreme events and disasters to advance climate change, A Special Report of Working Groups I and II of the Intergovernmental Panel on Climate Change, C.B. Field, V. Barros, T.F. Stocker, D. Qin, D.J. Dokken, K.L. Ebi, M.D. Mastrandrea, K.J. Mach, G.-K. Plattner, S.K. Allen, M. Tignor, P.M. Midgley (eds.), Cambridge University Press, 582 pp.

- IPCC, 2013, Climate Change 2013. The physical science basis, Working Group I Contribution to the Fifth Assessment Report of the Intergovernmental Panel on Climate Change, T.F. Stocker, D. Qin, G.-K. Plattner, M. Tignor, S.K. Allen, J. Boschung, A. Nauels, Y. Xia, V. Bex, P.M. Midgley (eds.), Cambridge University Press, 1585 pp.

- IPCC, 2014, Climate Change 2014. Impacts, adaptation, and vulnerability. Part A: Global and sectoral aspects, Contribution of Working Group II to the Fifth Assessment Report of the Intergovernmental Panel on Climate Change, C.B. Field, V.R. Barros, D.J. Dokken, K.J. Mach, M.D. Mastrandrea, T.E. Bilir, M. Chatterjee, K.L. Ebi, Y.O. Estrada, R.C. Genova, B. Girma, E.S. Kissel, A.N. Levy, S. MacCracken, P.R. Mastrandrea, L.L. White (eds.), Cambridge University Press, 1132 pp.

- Jaworski J., 2004, Parowanie w cyklu hydrologicznym zlewni rzecznych, Polskie Towarzystwo Geofizyczne, Warszawa, 422 pp.

- Kaczmarek Z., 1996, Wpływ niestacjonarności globalnych procesów geofizycznych na zasoby wodne Polski, Monografie Komitetu Gospodarki Wodnej PAN, 12, Oficyna Wydawnicza Politechniki Warszawskiej, Warszawa, 96 pp.

- Kaczmarek Z., Kindler J., 1989, The impacts of climate variability and change on urban and industrial water supply and wastewater disposal, [in:] Conference on Climate and Water, vol. 2, Academy of Finland, Helsinki, 161-176 - Kalinin G.P., 1968, Problemy globalnej gidrologii, Gidrometeoizdat, Leningrad, 51 pp.

- Kasperska-Wołowicz W., Łabędzki L., 2004, Porównanie ewapotranspiracji wskaźnikowej wg Penmana i Penmana-Monteitha w różnych regionach Polski, Woda-Środowisko-Obszary Wiejskie, 4 (2a), 123-136

- Kates R.W., Clark W.C., Corell R., Hall J.M., Jaeger C.C., Lowe I., McCarthy J.T., Schellnhuber H.J., Bolin B., Dickson N.M., Faucheux S., Gallopin G.C., Grübler S., Huntley B., Jäger J., Todha N.S., Kasperson R.E., Mabogunje A., Matson P., Mooney H., Moore III B., O’Riorden T., Svedin U., 2001, Sustainability science, Science. New Series, 292 (5517), 641-642

- Keller R., 1962, Gewässer und Wasserhaushalt des Festlandes, eine Einführung in die Hydrogeographie, B.G. Teubner, Leipzig, 520 pp.

- Kędziora A., 1995, Podstawy agrometeorologii, Państwowe Wydawnictwo Rolnicze i Leśne, Poznań, 264 pp.

- Kindler J., 2009, Gospodarka wodna i jej powiązania z inżynierią i ochroną środowiska w kontekście działań na rzecz trwałego i zrównoważonego rozwoju, [in:] Polska inżynieria środowiska pięć lat po wstąpieniu do Unii Europejskiej, Tom 3, M.R. Dudzińska, L. Pawłowski (eds.), Monografie Komitetu Inżynierii Środowiska PAN, 60, Lublin, 7-16

- Kindler J., 2014, Zasoby wodne dziś i jutro a perspektywy wyżywienia świata, [in:] Czy kryzys światowych zasobów?, B. Galwas, B. Wyżnikiewicz (eds.), Komitet Prognoz Polska 2000 Plus PAN, Dom Wydawniczy Elipsa, 199-211

- Kindler J., 2016, Droughts and Floods of Large Scale - Historical Analyses and Projections for the Future, Przyszłość. Świat-Europa-Polska, 2 (34), 59-70

- Konstantinov A.R., 1968, Isprarenije w prirodie, Gidromieteorologiczestkoje Izdatielstwo, Leningrad, $531 \mathrm{pp}$.

- Kowalczak P., 2008, Zagrożenia związane z deficytem wody, Wydawnictwo Kurpisz, Poznań, 256 pp.

- Kowalik P., 1995, Obieg wody w ekosystemach lądowych, Monografie Komitetu Gospodarki Wodnej PAN, 9, Warszawa, 84 pp.

- Kowalik P., 2010, Agrohydrologia obliczeniowa, Monografie Komitetu Gospodarki Wodnej PAN, 33, Warszawa, 82-150

- Kowalik P., Sanesi G., 1980, Simulazione della produttività reale e potenziale del suolo: alcuni esempi per i suoli idromorfi del Mugello, Firenze, CNR, 73 pp.

- Kovalenko P., Mikhaylov Y., 2008, Irrigation system control under uncertainty conditions, 
Journal of Water and Land Development, 12 (1), 27-36, DOI: 10.2478/v10025-009-0003-z

- Kożuchowski K.M., 2014, Meteorologia i klimatologia dla studentów leśnictwa, Wydawnictwo Uniwersytetu Łódzkiego, Łódź, 369 pp.

- Kuchar L., 2004, Using WGENK to generate synthetic daily weather data for modelling of agricultural processes, Mathematics and Computers in Simulation, 65 (1-2), 69-75, DOI: 10.1016/j.matcom.2003.09.009

- Kundzewicz Z.W., Kowalczak P., 2008, Zmiany klimatu i ich skutki, Wydawnictwo Kurpisz, Poznań, 214 pp.

- Kupczyk E., 1980, Matematyczny model topnienia pokrywy śnieżnej w zlewni rzecznej, Prace Badawcze IMGW. Seria Hydrologia, Warszawa, $128 \mathrm{pp}$.

- Lambor J., 1965, Podstawy i zasady gospodarki wodnej, Wydawnictwa Komunikacji i Łączności, Warszawa, 437 pp.

- Landsberg J.J., 1986, Physiological ecology of forest production, Academic Press, London, $198 \mathrm{pp}$.

- Lenartowicz M., Gutry-Korycka M., 2009, Regionalne uwarunkowania reakcji rzek na deszcze nawalne w warunkach rzeczywistych i w perspektywie globalnego ocieplenia klimatu, Prace i Studia Geograficzne, 43, 49-79

- Lettenmaier D.P., 1994, Modeling of runoff and streamflow at regional to global scales, NATO, ASI, Material of Conference, II Ciocco, Pisa, 27 May - 6 June

- Lewis S.L., 2012, We must set planetary boundaries wisely, Nature, 485, DOI: 10.1038/485417a

- Linsley R.K., Franzini J.B., 1972, Water Resources Engineering, McGraw-Hill, New York

- Lvovich M.I., 1974, World water resources and their future, (in Russian), “Mysl”, Moscow, 448 pp.

- Lwowicz M.S., 1969, Bilans wodny kuli ziemskiej oraz perspektywy wykorzystania i ochrony zasobów wodnych, Przegląd Geograficzny, 41 (3), 375-392

- Łabędzki L., 1997, Potrzeby nawodnień użytków zielonych, uwarunkowania przyrodnicze i prognostyczne, Rozprawy habilitacyjne, Wydawnictwo IMUZ, Falenty, 170 pp.

- Łabędzki L., 2004, Problematyka susz w Polsce, Woda-Środowisko-Obszary Wiejskie, 4 (1), 47-66

- Łabędzki L., 2006, Susze rolnicze. Zarys problematyki oraz metody monitorowania i klasyfikacji, Woda-Środowisko-Obszary Wiejskie. Rozprawy Naukowe i Monografie, 17, 107 pp.

- Łabędzki L., Adamowski P., 2010, Związek między opadami uprzednimi a uwilgotnieniem gleby w uprawie buraków cukrowych na Kujawach, Woda-Środowisko-Obszary Wiejskie, 10 (3), 165-174

- Łabędzki L., Bąk B., 2014, Meteorological and agricultural drought indices used in drought monitoring in Poland: a review, Meteorology, Hydrology and Water Management, 2 (2), 3-14, DOI: 10.26491/mhwm/34265

- Łabędzki L., Bąk B., Konecka-Geszke E., 2012, Wielkość i zmienność ewapotranspiracji wskaźnikowej według Penmana-Monteitha w okresie wegetacji w latach 1970-2004 w wybranych regionach Polski, Woda-Środowisko-Obszary Wiejskie, 12 (2), 159-170

- Maafs, 1870, Anderweitige Mittheilungen. Die Wasserstande der Elbe in den Jahren 1727 bis 1870, Atlas zur Zeitschift für Bouwesen, XX (1112), 496-502

- Maass A., Hufschmidt M.M., Dorfman, R., Thomas, H.A., Marglin, S.A., Maskew F.G., 1962, Design of water-resources systems, Harvard University Press, Cambridge, Massachusetts, 620 pp.

- Malinowski S., 2019, Not to be Ignored, ACADEMIA - The magazine of the Polish Academy of Sciences, 1 (6), 54-57

- Marcinek J., 2007, Hydrological cycle and water balance - a global survey, [in:] Global change: enough water for all?, J.L. Lozán, H. Grassel, P. Hupfer, L. Menzel, C.-D. Schönwiese (eds.), Wissenschaftliche Auswertungen, Hamburg, 33-37

- Matricon J., 2002, Woda. Cenniejsza niż złoto, Burda Media Polska, 143 pp.

- McMahon T.A., Finlayson B.L., Peel M.C., 2016, Historical developments of models for estimating evaporation using standard meteorological data, WIREs Water, 3 (6), 788-818, DOI: 10.1002/wat2.1172

- McMillan H., Montanari A., Cudennec C., Savenije H., Kreibich H., Krueger T., Liu J., Mejia A., Van Loon A., Aksoy H., Di Baldassarre G., Huang Y., Mazvimavi D., Rogger M., Sivakumar B., Bibikova T., Castellarin A., Chen Y., Finger D., Gelfan A., Hannah D.M., Hoekstra A.Y., Li H., Maskey S., Mathevet T., Mijic A., Pedrozo Acuna A., Polo M.J., Rosales V., Smith P., Viglione A., Srinivasan V., Toth E., van Nooyen R., Xia J., 2016, Panta Rhei 2013-2015: global perspectives on hydrology, society and change, Hydrological Sciences Journal, 61 (7), 1174-1191, DOI: 10.1080/02626667.2016.1159308

- Mikulski Z., 1998, Gospodarka Wodna, Wydawnictwo Naukowe PWN, Warszawa, 201 pp.

- Mikulski Z., 2006, Mark Isaakowicz Lwowicz (1906-1998) - w 100-lecie urodzin, Przegląd Geofizyczny, 51 (3-4), 245-248
- Milly P.C.D., Betancourt J., Falkenmark M., Hirsch R.M., Kundzewicz Z.W., Lettenmaier D.P., Stouffer R.J., 2008, Stationarity is dead: whither water management, Science, 319 (5863), 573-574, DOI: 10.1126/science.1151915

- Mioduszewski W., 2003, Gospodarka wodna w rolnictwie na III Światowym Forum Wody, Wiadomości Melioracyjne i Łąkarskie, 3, 142-145

- Mioduszewski W., 2006, Woda wirtualna woda do produkcji żywności, Gospodarka Wodna, 5, 173-178

- Mioduszewski W., 2008, Kilka uwag dotyczących gospodarowania rolniczymi zasobami wodnymi, Wiadomości Melioracyjne i Łąkarskie, 4, 69-198

- Montanari A., Young G., Savenije H.H.G., Dughes D., Wagener T., Ren LKoutsoyiannis D., Cudennec C., Toth E., Grimaldi S., Bloschl G., Sivapalan M., Beven K., Gupta H. Hipsey M., Schaefli B., Arheimer B., Boegh E., Schymanski S.J., Di Baldassarre G., Yu B., Hubert P., Huang Y., Schumann A., Post D.A., Srinivasan V., Harman C., Thompson S., Rogger M., Viglione A., McMillan H., Characklis G., Pang Z., Belyaev V., 2013, "Panta Rhei - everything flows": change in hydrology and society - The IAHS Scientific Decade 2013-2022, Hydrological Sciences Journal, 58 (6), 1256-1275, DOI: 10.1080/02626667.2013.809088

- Monteith J.L., 1965, Evaporation and environment, Symposia of the Society for Experimental Biology, 19, 205-234

- Monteith J.L., 1981, Climatic variation and the growth of crops, Quarterly Journal of the Royal Meteorological Society, 107 (454), 749-774, DOI: 10.1002/qj.49710745402

- Monteith J.L., 1985, Evaporation from land surfaces: progress in analysis and prediction since 1948, [in:] Advances in evapotranspiration: proceedings of the National Conference on Advances in Evapotranspiration, December 16-17, Chicago, II ASEA, St. Joseph, Michigan, 4-12

- Monteith J.L. (ed.), 1975, Vegetation and the atmosphere. Volume 1: Principles, Academic Press, London, 298 pp.

- Monteith J.L. (ed.), 1976, Vegetation and the atmosphere. Volume 2: Case studies, Academic Press, London, 278 pp.

- Morley H., 1852, The life of Bernard Palissy of Sainties, Cassell Petter \& Galpin, London, Paris, New York, 344 pp.

- Newton D.E., 2003, Encyclopedia of water, Greenwood Press, West Post, Connecticut, London, 424 pp. 
- Ojima D. (ed.), 1992, Modeling the Earth system, Boulder, Colorado, $498 \mathrm{pp}$.

- Owens L.B., Watson J.P., 1979, Rates of weathering and soil formation on granite in Rhodesia, Soil Science Society of America Journal, 43 (1), 160-166, DOI: 10.2136/sssaj1979.03615995004300010031x

- Ozga-Zielińska M., Brzeziński J., 1994, Hydrologia stosowana, Wydawnictwo Naukowe PWN, Warszawa, 323 pp.

- Penman H.L., 1956, Evaporation: an introductory survey, Netherlands Journal of Agricultural Science, 4, 9-29

- Poljanšek K., Marin Ferrer M., De Groeve T., Clark I., 2017, Science for disaster risk management 2017: knowing better and losing less. Publications Office of the European Union, Brussels, DOI: 10.2788/842809

- Priestley C.H.B., Taylor R.J., 1972, On the assessment of surface heat flux and evaporation using large-scale parameters, Monthly Weather Review, 100 (2), 81-92, DOI: 10.1175/1520-0493(1972)100<0081:OTAO $\mathrm{SH}>2.3 \mathrm{CO} ; 2$

- Rahaman M.M., Varis O., 2005, Integrated water resource management: evolution, prospects and future challenges. Sustainability: Science, Practice and Policy, 1 (1), 15-21, DOI: 10.1080/15487733.2005.11907961

- Renault D., 2002, Value of virtual water in food: principles and virtues, UNESCO-IHE Workshop on Virtual Water Trade, Delft, The Netherland, available at http://www.fao.org/3/ap527e/ ap527e.pdf (data access 08.08.2019)

- Richter J.P., 2016, The literary works of Leonardo da Vinci. Compiled and edited from the original manuscripts, volume 2, Classic Reprint Series, FB \&C LTD, 648 pp.

- Rijsberman F.R. (ed.), 2000, World Water Scenarios: Analyses, (ed.), Earthscan, London, UK

- Rijsberman F.R., 2006, Water scarcity: Factor or fiction?, Agriculture Water Management, 80, (1-3), 5-22, DOI: 10.1016/j.agwat.2005.07.001

- Rijtema P.E., 1969, On the relation between transpiration, soil physical properities and crop production as a basis for water supply plants, [in:] Soil, Water, Plant, Proceedings and Information No 30, Committee for Hydrological Research TNO Gravenhage, 28-58

- Rijtema P.E., Endrödi G., 1970, Calculation of production of potatoes, Netherlands Journal of Agricultural Science, 18 (1), 26-36

- Rockström J., Falkenmark M., Allan T., Folke C., Jägerskog A., Kummu M., Lannerstad M., Meybeck M., Molden D., Postel S., Savenije H.H.G.,
Svedin U., Turton A., Varis O., 2014a, The unfolding water drama in the Anthropocene: towards a resilience-based perspective on water for global sustainability, Ecohydrology, 7 (5), 1249-1261, DOI: 10.1002/eco.1562

- Rockström J., Falkenmark M., Folke C., Lannerstad M., Barron J., Enfors E., Gordon L., Heinke J., Hoff H., Pahl-Wolst C., 2014b, Water resilience for human prosperity, Cambridge University Press, Cambridge, DOI: 10.1017/ CB09781139162463

- Rockström J., Steffen W., Noone K., Persson A., Chapin F.S.III, Lambin E., Lenton T.M., Scheffer M., Folke C., Schellnhuber H.J., Nykvist B., de Wit C.A., Hughes T., van der Leeuw S., Rodhe H., Sörlin S., Snyder P.K., Costanza R., Svedin U., Falkenmark M., Karlberg L., Corell R.W., Fabry V.J., Hansen J., Walker B., Liverman D., Richardson K., Crutzen P., Foley J., 2009, Planetary boundaries: exploring the safe operating space for humanity, Ecology and Society, 14 (2), 32

- Rodda J.C., 1963, Eighteenth century evaporation experiments, Weather, 18 (9), 264-269, DOI: 10.1002/j.1477-8696.1963.tb02028.x

- Ross J., 1970, Mathematical models of photosynthesis productivity, [in:] Prediction and measurement of photosynthetic productivity. Proceedings of the IBP/PP technical meeting, Třeboň, 14-21 September, 1969, PUDOC, Wageningen, 29-46

- Sadler B.S., 1991, Implementing awareness of water in societal planning and decision-making - means and obstacles, [in:] Water awareness in social planning and decision-making, L. Johanesson (ed.), Proceedings of the International Workshop Skokloster, Swedish Council for Building Research, Stockholm, 43-60

- Schierbeek E.W. (ed.), 1980, Research digest 1980, Institute for Land and Water Management Research, Technical Bulletin No 117, Wageningen, The Netherlands, $229 \mathrm{pp}$.

- Slabbers P.J., 1979, Surface roughness of crops and potential evapotranspiration, Journal of Hydrology, 34 (1-2), 181-191, DOI: 10.1016/0022-1694(77)90070-1

- Soczyńska U., 1995, Modelowanie systemów naturalnych, Wydawnictwo Uniwersytetu Warszawskiego, Warszawa, 59 pp.

- Soczyńska U. (ed.), 1997, Hydrologia dynamiczna, Wydawnictwo Naukowe PWN, Warszawa, 409 pp.

- Soczyńska U., Gutry-Korycka M., Pokojska P., Mikos D., 2003, Water balance as a base for proper water management in the Łasica catchment (Kampinos National Park), Ecohydrology and Hydrobiology, 3 (3), 291-309

- Sokolov A.A., Chapman T. (eds), 1971, Scientific framework of world water balance. A contribution to the International Hydrological Decade, Technical papers in hydrology, 7, NESCO, Paris, available at https://hydrologie.org/BIB/ Publ_UNESCO/TP_007_E.pdf (data access 08.08.2019)

- Springmann M. Clark M., Mason-D’Croz D., Wiebe K., Bodirsky B.L., Lassaletta L., de Vries W., Vermeulen S.J., Herrero M., Carlson K.M., Jonell M., Troell M., DeClerck F., Gordon L.J., Zurayk R., Scarborough P., Rayner M., Loken B., Franzo J., Godfray H.C.J., Tilman D., Rockström L., Willet W., 2018, Options for keeping the food system within environmental limits, Science, 562, 519252, DOI: 10.1038/s41586-018-0594-0

- Stanhill G., 1960, The relationships between climate and transpiration and growth of pastures, [in:] Proceedings of the $8^{\text {th }}$ International Grassland Congress, University of Reading, 11-21 July

- Steffen W., Richardson K., Rockström J., Cornell D., Fetzer J., Bennett E.M., Biggs R., Carpenter S.R., de Vries W., de Wit C.A., Fole C., Gerten D., Heinke J., Mace G.M., Persson L.M., Ramanathan V., Reyers B., Sörlin S., 2015, Planetary boundaries: Guiding human development on a changing planet, Science, 347 (6223), DOI: 10.1126/science.1259855

- Stern N., 2006, The economics of climate change. The Stern review, Cambridge University Press, DOI: 10.1017/CBO9780511817434

- Stern N., 2019, A story of growth, ACADEMIA - The magazine of the Polish Academy of Sciences, 1 (6), 16-21

- Szymkiewicz R., Gąsiorowski D., 2010, Podstawy hydrologii dynamicznej Wydawnictwo Naukowo-Techniczne, Warszawa, 290 pp.

- Tallaksen L.M., Van Lanen H.A.J. (eds.), 2004, Hydrological drought. Processes and estimation methods for streamflow and groundwater, Developments in Water Science Series, 48, Elsevier Science B.V., 579 pp.

- Tarboton D.G., Chowdhury T.G., Jackson T.H., 1994, A spatially distributed energy balance snowmelt model, Working Paper WP-94HWR-DGT/003, Utah Water Research Laboratory, Utah State University, available at https:// digitalcommons.usu.edu/cgi/viewcontent. cgi?article=1059\&context=water_rep (data access 08.08.2019)

- Thornthwaite C.W., Mather J.R., 1957, Instructions and tables for computing potential 
evapotranspiration and water balance, Publication in Climatology, 10 (3), 311 pp.

- Turc L., Pike J.G., 1964, Évapotranspiration potentiale etp décadaire, Son evolution en function de olénuées méteorologique, [in:] Polsko-Francuskie Sympozjum Gospodarki Wodnej, 13, IGW, WKiŁ, Warszawa

- UN, 2013, A new global partnership: eradicade poverty and transform economies through sustainable development. The Report of the High-level Panel of Eminent Persons on the Post-2015 Development Agenda, available at https://www.un.org/sg/sites/www. un.org.sg/files/files/HLP_P2015_Report.pdf (12.08.2019)

- UN, 2014, A post-2015 global goal for water: Synthesis of key findings and recommendations from UN-Water, available at https://www. un.org/waterforlifedecade/pdf/27_01_2014_ un-water_paper_on_a_post2015_global_ goal_for_water.pdf (data access 08.08.2019)

- UN, 2015, The millennium development goals report, 2015, United Nations, New York, available at https://www.un.org/millenniumgoals/2015_MDG_Report/pdf/MDG\%20 2015\%20rev\%20(July\%201).pdf (data access 08.08.2019)

- UN, 2018, Nature-based solutions for water, The United Nations World Water Development Report 2018, UN Water, UNESCO, France, available at https://reliefweb.int/sites/reliefweb. int/files/resources/261424e.pdf (data access 08.08.2019)

- UNDP, 2006, Human Development Report 2006, United Nations Development Programme, New York, available at http://hdr. undp.org/sites/default/files/reports/267/ hdr06-complete.pdf (data access 08.08.2019)

- UNESCO, 1971, Scientific framework of world water balance, Technical Papers in Hydrology, 7, UNESCO, Paris, available at https://unesdoc. unesco.org/ark:/48223/pf0000073095 (data access 08.08.2019)
- Varis O., Keskinen M., Kummu M., 2017, Four dimensions of water security with a case of the indirect role of water in global food security, Water Security, 1, 36-45, DOI: 10.1016/j. wasec.2017.06.002

- Veldkamp T.I.E., Wada Y., de Model H., Kummu M., Eisner S., Aerts J.C.J.H., Ward P.J., 2015, Changing mechanism of global water scarcity events: Impacts of socioeconomic changes and inter-annual hydro-climatic variability, Global Environmental Change, 32, 18-29, DOI: 10.1016/j.gloenvcha.2015.02.011

- Vörösmarty C.J., McIntyre P.B., Gessner M.O., Dudgeon D., Prusevich A., Green P., Glidden S., Bunn S.E., Sullivan C.A., Reidy Liermann C. Davies P.M., 2010, Global threats to human water security and river biodiversity, Nature, 467 (7315), 555-561

- Vörösmarty C.J., Pahl-Wostl C., Bhaduri A., 2013, Water in the anthropocene: New perspectives for global sustainability, Current Opinion in Environmental Sustainability, 5 (6), DOI: 10.1016/j.cosust.2013.11.011

- WCRP, 2013, The World Climate Research Programme: Accomplishment report, WCRP, Geneva, available at https://www.wcrp-climate.org/images/documents/reports_flyers/WCRP_report03_2012.pdf (data access 08.08.2019)

- Weigelhofer G., Welti N., Hein T., 2013, Limitations of stream restoration for nitrogen retention in agricultural headwater streams, Ecological Engineering, 60, 224-234, DOI: 10.1016/j.ecoleng.2013.07.057

- Weizsäcker U.E. von, Wijkman A., 2018 Come On! Capitalism, short-termism, population and the destruction of the planet, Club of Rome, Springer, 220 pp., DOI: 10.1007/9781-4939-7419-1

- Wibig J., 2012, Warunki wilgotnościowe w Polsce w świetle wskaźnika standaryzowanego klimatycznego bilansu wodnego, Woda Środowisko-Obszary Wiejskie, 12 (2), 329-340
- Wibig J., 2017, Klimatyczny bilans wodny, [in:] Hydrologia Polski, P. Jokiel, W. Marszelewski, L. Pocias-Karteczka (eds.), Wydawnictwo Naukowe PWN, Warszawa, 49-54

- Wilson W.T., 1941, An outline of the thermodynamic of snowmelt, [in:] Proceedings of the $9^{\text {th }}$ Annual Western Interstate Snow Survey Conference, American Geophysical Union, Transactions, Part I-B, Sacramento, California

- WMO, 1988, Hydrological Operational Multipurpose Subprogramme (HOMS): reference manual, $2^{\text {nd }}$ edition, World Meteorological Organization, Geneva

- WMO, 1994, Guide to hydrological practices, WMO No 168, sixth edition, Geneva, available at http://www.whycos.org/hwrp/guide/index. php (data access 08.08.2019)

- WWAP/UN-Water, 2015, The United Nations World Water Development Report 2015: Water for a Sustainable World, UNESCO Paris, available at https://unesdoc.unesco. org/ark:/48223/pf0000231823 (data access 02.07.2019)

- WWAP/UN-Water, 2018, The United Nations World Water Development Report 2018: Nature-Based Solutions for Water, UNESCO, Paris, available at https://unesdoc.unesco. org/ark:/48223/pf0000261424 (data access 02.07.2019)

- WWF, 2014, Living Planet Report 2014. Species and spaces, people and places, WWF available at https://www.worldwildlife.org/ pages/living-planet-report-2014 (data access 02.07.2019)

- Wypych A., Henek E., 2012, Wykorzystanie GIS w badaniach zróżnicowania klimatycznego bilansu wodnego w Polsce, Przegląd Geofizyczny, 58 (2), 79-90

- Wypych A., Kowanetz L., 2017, Parowanie terenowe i ewapotranspiracja, [in:] Hydrologia Polski, P. Jokiel, W. Marszelewski, J. Pociask-Karteczka (eds.), Wydawnictwo Naukowe PWN, Warszawa, 44-49 